EXEMPLARIa Classica

Journal of Classical Philology

15, 2011, pp. 3-45

ISSN 1699-3225

\title{
PARÁFRASIS HOMÉRICAS EN PAPIROS, TABLILLAS Y ÓSTRAKA
}

\author{
José Antonio Fernández Delgado \\ Universidad de Salamanca \\ jafdelgado@usal.es
}

\section{RESUMEN}

Entre el abundante material exegético del texto homérico que los papiros y otros tipos de soporte escriturario transmiten, reflejo de aquellos papiros que en muchísimo mayor número transmiten porciones del propio texto, un lugar muy significativo ocupan las paráfrasis o versiones homéricas en prosa de su propia época, distintas de los llamados scholia minora y de las hypotheseis, y de las cuales se echaba en falta un estudio de conjunto. Las muestras aquí reunidas se distribuyen a lo largo de un lapso de tiempo que va al menos del s. I al VI-VII d. C., ilustran los diversos métodos de la paráfrasis llamada gramatical (versión a partir de glosas) y de la paráfrasis de tipo retorizante, unas y otras muestras pertenecen en gran parte al ámbito escolar o bien están destinadas a un público más amplio, y adoptan distintas modalidades de ejecución y distintos formatos en su afán de hacer llegar el texto del poeta por excelencia a lectores cada vez menos eruditos.

Palabras Clave

Paráfrasis, material exegético, texto homérico, papiros

\section{ABSTRACT}

Among the abundant exegetic material on the Homeric text which has been transmitted on papyri and similar materials -a reflection of those which in a considerably higher number convey Homeric passages- paraphrases or prose versions of the Homeric text take a very significant place. This is a different genre from the so-called scholia minora or the hypotheseis, and it has not yet been comprehensively studied. The items which I gather here range at least from the first to the seventh century $\mathrm{AD}$ and illustrate different methods of the so-called grammatical paraphrasis (taking glossae as its starting point) and the rhetorical paraphrasis, both closely related to the school or aimed at a wider public. Different forms and patterns are chosen to bring the text of the poet par excellence closer to readers who are less and less learned as time passes by.

\section{KEY WORDS}

Paraphrases, exegetic material, Homeric text, papyri

Fecha de recepción: 28/06/2011

Fecha de aceptación y versión final: 29/07/2011 
Entre el abundante material exegético de los textos homéricos que los hallazgos papiráceos han ido proporcionando*, reflejo de los papiros que, en mucho mayor número, contienen el propio texto de Homero haciendo de este su autor mejor representado con gran diferencia, un lugar relativamente importante y desde luego significativo ocupan las diversas muestras de paráfrasis. Como ejercicio literario es esta conocida ya al menos desde la época de Platón ${ }^{1}$ y su ámbito de definición puede decirse que abarca el amplio espacio que media entre los copiosos scholia minora o material básicamente lexicográfico y los resúmenes o hypotheseis. Un criterio importante de delimitación con respecto a los primeros es que, a diferencia de estos, la paráfrasis es autónoma con respecto al texto en que se basa; sin embargo hay casos en que la paráfrasis se presenta no por sí sola, sino acompañando al texto parafraseado, como ocurre con los escolios; y de ahí la no infrecuente falta de precisión en los usos terminológicos por parte de los estudiosos ${ }^{2}$. No solo por esta razón, sino también porque desde hace ya tiempo se echa de menos, en unos casos naturalmente más que en otros, un estudio actualizado de las paráfrasis homéricas conocidas por vía papirácea ${ }^{3}$, nos ha parecido oportuno abordar dicha tarea desde una visión de conjunto ${ }^{4}$. He de decir, no obstante, que mi eventual aportación al tema, aparte de la compilación de un material nunca fácil de reunir y menos de agotar, no pretende incidir tanto en los problemas de edición de los diversos testimonios, como en su capacidad de ilustrar las diversas posibilidades de la técnica parafrástica y las pautas de su aprendizaje. Lo cual en parte permitirá contraponer la incidencia del ejercicio parafrástico en el medio escolar frente a cierta tendencia de los estudiosos a considerarlo básicamente en lo que tiene de derivación de la filología alejandrina y aristarquea de Homero.

Para ello procederé a analizar los testimonios por orden aproximado de antigüedad, empezando por referirme a una serie de ellos que provienen ya de época helenística y son muy fragmentarios (I), aunque no tanto como

* El presente trabajo se enmarca en el Proyecto de Investigación "La retórica escolar griega: su incidencia en los papiros, su influencia en la literatura y sus modelos literarios" (FFI201021125 [FILO]).

${ }^{1}$ R. 393d ss., paráfrasis de $I l$.1.12-42 cuyo objeto es servir de ilustración al problema de la mímesis.

${ }^{2}$ Cf. F. Montanari, Studi di Filologia Omerica Antica, Pisa 1995, 2, 69ss., 81-2.

${ }^{3}$ Cf. F. Montanari, Studi di Filologia Omerica Antica, Pisa 1979, 1, 11, el cual se refiere en concreto al "pésimo estado en que se halla la situación editorial de las paráfrasis homéricas".

${ }^{4}$ Las paráfrasis homéricas contenidas en material papiráceo de probable raigambre escolar han sido estudiadas aparte en J. A. Fernández Delgado, "La parafrasi omerica nei papiri scolastici”, I Papiri Omerici (Convegno Internazionale, Università degli Studi di Firenze, 9-10 giugno 2011), en prensa. De dos de las paráfrasis incluidas en el presente trabajo que por su entidad así lo aconsejan, ofrecemos también la traducción, en un caso (Bodleian Greek Inscription 3019) la primera a una lengua moderna y en otro $(P . O x y$. 3002) la primera al español (el editor del papiro, P. Parsons, $P$. Oxy. XLII, 3002, 1974, 13-5, proporciona su traducción al inglés) de las que tenemos noticia. 
para que su controvertida identificación haya llevado habitualmente a pensar en paráfrasis en lugar de resúmenes, y terminando con otros que han sido datados hasta los siglos VI y VII d. C. y presentan asimismo problemas de clasificación (III).

De entre los discutidos testimonios de época helenística de los que he hablado, P. Hamb. II 136, atribuido a la primera mitad del s. III a. C. por su editor, B. Snell, contiene el pasaje de Il. II (101-109) que describe los sucesivos posesores del cetro de Agamenón, seguido de una discusión en prosa cuyas líneas no se dejan reconstruir ; $P$. Strasb. G. inv. 2374, atribuido al s. III a. C. y considerado escolar por su editor, N. Lewis ${ }^{6}$, en el verso de un texto relativo a la caza contiene restos de un resumen en prosa del canto 6 de Ilíada que, por lo que se ve, anticipa los ocho versos que siguen (6.448-55) de la célebre escena de la despedida de Héctor y Andrómaca y son seguidos a su vez de un texto aparentemente en prosa del que queda algún resto; $P$. Vindob. Gr. inv. 26740, situado en el s. II d. C. por su editor, H. Oellacher ${ }^{7}$, y considerado también escolar por sus muchas faltas, conserva dos columnas de texto de las cuales la primera contiene los vv. 387-403 de Il. 6 y la segunda los vv. 404-10 seguidos de dos pasajes en prosa muy mutilados y separados por una parágraphos, pasajes que el editor cree que son resumen de lo anterior.

Posteriormente G. Nachtergael, en un trabajo que ha sido muy citado ${ }^{8}$, postula que tanto $P$. Vindob. Gr. inv. 26740 como $P$. Hamb. II 136 podrían contener, al igual que $P$. Strasb. G. inv. 2374, un resumen no de lo anterior sino del pasaje siguiente (hasta $I l$. 6.416 y hasta $I l$. 2.210ss. respectivamente) y, de forma no muy convincente, intenta ver en todos ellos antologías homéricas, no precisamente escolares, de secciones en prosa y memorables secciones en verso alternadas, de acuerdo con un modelo supuestamente expuesto ya por Platón ( Lg. 811a) y todavía hoy perdurable. La propuesta de Nachtergael ha sido rebatida por M. E. Van Rossum-Steenbeck ${ }^{9}$, quien, tras nuevas lecturas de algunos de estos y otros papiros posteriormente implicados (P. Ien. inv. 659r, P. Bryn Mawr 1, 8; P. Mich. inv. 4832c), pone en duda, primero, que tal concepto de antología pueda remontarse a una determinada

${ }^{5}$ En opinión de su editor, Griechische Papyri der Hamburger Staats- und Universitätsbibliothek mit einigen Stücken aus der Sammlung Hugo Ibscher, Hamburg 1954, 85-6: "Die ersten Zeilen enthalten B 101-109, aber dann folgt irgendeine Erörterung in Prosa. Leider lässt sich der Zusammenhang dieser Zeilen nicht herstellen".

6 "Greek Literary Papyri from the Strasbourg Collection", Études de Papyrologie 3, 1936, 46-92 (46-49).

7 "Griechische literarische Papyri aus der Papyrussammlung Erzherzog Rainer in Wien", Études de Papyrologie 4, 1938, 133-5.

8 "Fragments d'anthologies homériques (P. Strasb. inv. 2374; P. Graec. Vindob. 26740; P. Hamb. II 136)", Cd'E 46, 1971, 344-51.

9 "The so-called "Homeric anthologies", en Akten des 21. Internationalen Payrologenkongresses, Berlin 1995, Archiv für Papyrusforschung. Beiheft 3, 1997, 991-5. 
cita platónica ( $L g .811$ ) y, segundo, que los testimonios discutidos respondan también a la idea de Nachtergael.

De P. Strasb. G. inv. 2374, N. Lewis, en cuya edición se basa Nachtergael, ofrece solamente el texto de su segunda columna porque, según él, de la col. I "las pocas letras legibles no merecen la pena de ser reproducidas"10; sin embargo una fotografía del papiro permitió a M. E. Van Rossum-Steenbeck identificar no solo parte de los restos de la col. I como provenientes de $\mathrm{Il}$. 6.429-34 (parte de la réplica de Andrómaca a Héctor), a los cuales siguen escasos restos de siete líneas que parecen ser prosa, sino que también demostró que las dos últimas líneas de la col. II contienen $\mathrm{Il}$. 6.464-5 en vez de prosa como se creía, siendo estos versos precedidos por $I l .6 .448-55$ y ambas tiradas (parte media y final del discurso de Héctor a Andrómaca) por una sección en prosa encabezando la columna. Dicha sección parece referirse al texto citado (declaración de Héctor de que ama a Andrómaca más que a sus padres y de que sus palabras no pretenden asustar a esta, pero lo consiguen) y no resumir todo el canto 6 como entienden Lewis y Nachtergael ${ }^{11}$. De P. Vindob. Gr. inv. 26740 a su vez P. J. Sijpesteijn y K. A. Worp han demostrado que la

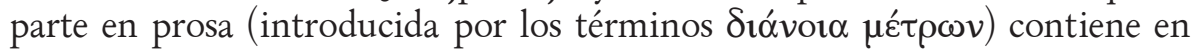
realidad no un resumen de parte de $I l .6$ sino dos problemas de conversión, a los cuales precede $I l$. 6.373-410 y antes cinco problemas de geometría ${ }^{12}$. De $P$. Hamb. 2.136, cuya parte en prosa conjetura Nachtergael que resume lo que sigue al texto de $I l .2 .101-9$ hasta el episodio de Tersites (211ss.), la citada estudiosa se inclina más por la explicación de $\mathrm{H}$. Erbse $^{13}$ de que puede tratarse de una disertación sobre el cetro de Agamenón o sobre su uso, de modo que los versos serían incluidos a modo de ilustración.

Con respecto a los otros tres papiros posteriormente implicados en la discusión sobre el tipo de antología homérica propuesto por Nachtergael, $P$. Ien. inv. 659r contiene $\mathrm{Il}$. 9.32-6 (comienzo de un discurso de Diomedes) precedido de unos escasos restos de letras y seguido por otros que los editores se inclinan a pensar que se trata de un tipo de paráfrasis, aun cuando su explicación suena más a resumen, y a cuyo fin remiten al trabajo de Nachtergael: "Näher liegt es deshalb, bei den Zeilen 1, 2 und 8 an eine Paraphrase zu denken, durch die im Wechsel mit zitierten Homerversen grössere Textpartien zusammengefasst werden sollten" ${ }^{14}$; en opinión de la citada estudiosa los restos son tan

${ }^{10}$ Études de Papyrologie 3, 1936, 46-7.

${ }^{11}$ Una observación similar se encuentra, sin duda no por casualidad, en los escolios a $I l$. 6.448a1, a2, cf. H. Erbse, Scholia Graeca in Homeri Iliadem 2, Berlin 1971.

${ }^{12}$ El texto homérico ha sido reeditado por P. J. Sijpesteijn \& K. A. Worp, "Literary and Semi-literary Papyri from the Vienna Papyrus Collection”, $C$ d’ E 49, 1974, 309-13; los problemas matemáticos son discutidos por E. M. Bruins, P. J. Sijpesteijn \& K. A. Worp, Janus 61, 1974, 297-312.

${ }^{13}$ H. Erbse, Scholia Graeca in Homeri Iliadem I, Berlin 1969, XLIII-XLIV.

${ }^{14}$ Editio princeps por C. F. Collatz \& G. Poethke, "Zwei Papyri zu homerischen Reden", $A P F$ 29, 1983, 13-5, quienes fechan el papiro a mediados del s. III a. C. 
escasos que lo mismo pueden ser prosa o verso, permitiendo solamente hacer conjeturas y no sacar conclusiones. En P. Bryn Mawr 1, 8, aunque sus restos son también fragmentarios su editor ${ }^{15}$, evocando el trabajo de Nachtergael, distingue "una relación sumaria de ciertos sucesos" de $I l .1$ entre los que un verso, $I l .1 .36$, ha sido insertado, mientras que la estudiosa piensa que el texto adyacente puede ser un resumen pero también una historia o un comentario sobre Apolo. P. Mich. inv. $4832 \mathrm{c}^{16}$ sería el único testimonio que parece encajar en la idea de antología expuesta por Nachtergael, en la medida en que la parte conservada de su col. I comienza con el final del catálogo de las Nereidas (Il. 18.45-9) y probablemente continúa con un resumen del texto homérico subsiguiente, en la col. II los versos de $I l .19 .38-9$ (en que Tetis intenta conservar el cuerpo de Patroclo) son seguidos de un resumen en prosa de los versos 40-304 (sobre la reconciliación de Agamenón y Aquiles), en medio del cual ha sido insertado el v. 176 de $I l$. 19; sin embargo, en contraposición a los versos del catálogo citado, que como todos los catalógicos son objeto frecuente de los textos papiráceos ${ }^{17}$, no es probable que los versos 38-9 y luego el v. 176 del canto 19 hayan sido incluidos por su relevancia en una selección de pasajes memorables, de modo que la estudiosa considera que lo importante del texto es lo que tiene de resumen y no sus ocasionales citas literales.

En cualquier caso parece improbable que cualquiera de estos textos se trate de paráfrasis (como a algunos califica la LDAB (Leuven Database of Ancient Books): P. Strasb. G. inv. 2374 (LDAB 2381), P. Vindob. Gr. inv. 26740 (LDAB 1723), o CEDOPAL (Centre de Documentation de Papyrologie Littéraire, de l'Université de Liège) ( $P$. Ien. inv. 659r)) si no es en la medida en que un resumen puede ser considerado manifestación -algo así como el grado máximo de concentración- de la misma. Sin embargo, el resumen de un pasaje o un texto homérico más amplio es un tipo de ejercicio bien conocido (hypóthesis), ya sea como primera aproximación a la lectura de los textos ya sea como recapitulación o recordatorio después de aquella, en la propedéutica de la poesía homérica y en sus muestras papiráceas, al margen de la paráfrasis ${ }^{18}$.

${ }^{15}$ T. Renner, "The Bryn Mawr Papyri” (nº 2), BASP 22, 1985, 273-7.

${ }^{16}$ Publicado por T. Renner, "Three new Homerica on Papyrus”, HSCPh 83, 1979, 331-7, quien lo fecha a caballo entre s. II y I a. C. y califica su escritura de "insegura mano libresca tardo-ptolemaica característica” (331-2).

${ }^{17}$ Cf. infra n. 26.

${ }^{18}$ Cf. G. Nachtergael, Cd'E 46, 1971, 344 n. 3; F. Montanari, Studi di Filologia Omerica, 2,77-9. 
II

He aquí el dossier de aquellos textos de los que sí creo que hay buenas razones para considerarlos paráfrasis:

PSI XII 1276 Ro (LDAB 2270=Mertens-Pack 1172)

El texto que aquí interesa ${ }^{19}$ ocupa el recto de un fragmento de rollo de papiro (de $13 \times 25 \mathrm{~cm}$.) cuyo verso, vacío en su mayor parte, contiene escasos restos de un horóscopo pero los justos para poder ver la fecha de su escritura, el 26 de mayo del año $32 \mathrm{~d}$. C., y con ello establecer un terminus ante quem para el escrito del recto, el cual presenta una escritura de tipo literario, sin acentos ni signos de interpunción, cuya fecha ha sido situada en el s. I d. C. ${ }^{20}$

El texto se dispone en dos columnas de las cuales a la primera le falta más de la mitad izquierda y a la segunda la mayor parte por la derecha, faltando igualmente el comienzo de la primera columna y el final de la segunda así como los bordes superior e inferior. Los restos de la primera columna corresponden a 22 versos del canto 2 de la Ilíada (617-38), parte del catálogo de fuerzas que constituían la flota enviada a Troya por los griegos, y los de la segunda columna a los 32 siguientes (639-70) del mismo canto, si bien se calcula que el número total de versos comprendidos serían 35 en cada caso. Siendo así, la primera columna recogería desde el segundo verso dedicado a la región de Arcadia (v. 604), seguida de la región de Bufrasio y la Élide, la de Duliquio y las islas Equinas, ambas enfrente de la anterior, hasta las fuerzas aportadas por Odiseo. La segunda columna recogería desde el segundo verso dedicado a la región de Etolia (v. 639) las fuerzas aportadas por la región de Creta, las aportadas por Rodas, cuya enumeración se detiene más de lo habitual en la peripecia vital de su caudillo Tlepólemo, hijo de Heracles, y finalmente la aportación de Nireo de Sime, cuya descripción como "el hombre más hermoso que acudió a Ilión" (v. 673) deja ya fuera el resto de la frase que la relativiza ("de entre todos los Dánaos después del irreprochable Pelida").

Entre verso y verso de la Ilíada, destacados en ékthesis, el texto incluye lo que podemos llamar la traducción literal en prosa de la época del papiro, del respectivo verso anterior. Como veremos, no es el único ejemplo de esta clase de paráfrasis homérica proporcionado por los papiros, la cual ha sido calificada por Lehrs de "gramatical", en contraposición al tipo de paráfrasis más elaborada o "retórica" 1 . Su intención es verter el contenido del verso en términos gramatical y léxicamente comprensibles sin sobrepasar la medida

${ }^{19}$ Ed. V. Bartoletti, PSI 12, 1276, 114-9; versión más amplia en Aegyptus 19, 1939, 177-86.

${ }^{20}$ Datado por su editor en el s. I a. C., los editores del CDRom Papiri Letterari della Biblioteca Medicea Laurenziana (Università degli Studi di Cassino, 2002) lo fechan a comienzos del s. I d. C., aduciendo como paralelos de su escritura - de módulo pequeño, ductus cursivo y poco esmerado, de trazado apenas redondo y uniforme y eje erguido aunque algunas letras tienden a inclinarse a la derecha- P. Ryl. II 131 (31 a. C.) y P. Paris. 71=P. Louvre E 3320 (s. I d. C.), además del terminus ante quem proporcionado por la fecha del horóscopo.

${ }^{21}$ K. Lehrs, Die Pindarscholien, Leipzig 1873, 50ss. 
del verso ni forzar el orden de palabras del original más que lo estrictamente necesario. Se trata en realidad de una muestra temprana del tipo de paráfrasis homérica habitual en época bizantina avanzada, obra a veces de autores conocidos, como Miguel Pselo o Manuel Moscópulo, y transmitida por una serie de manuscritos ${ }^{22}$. De este tipo de paráfrasis gramatical en ámbito escolar posiblemente surgieron y luego se desmembraron los escolios propiamente dichos, siendo la paráfrasis a su vez un paso más con respecto a la practicada anteriormente por la crítica aristarquea de Homero no solo con términos aislados sino también con expresiones ${ }^{23}$.

Limitándonos a las secuencias de la paráfrasis papirácea no reconstruidas y por tanto seguras, podemos señalar como manifestaciones características de la citada técnica de adaptación del contenido del verso a la prosa coetánea del testimonio las siguientes entre otras:

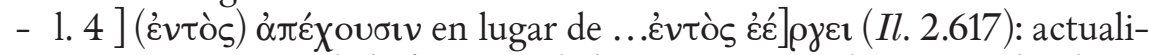
zación prosística de la forma verbal épica y concordancia en plural con sujeto múltiple en lugar de singular con el sujeto más próximo.

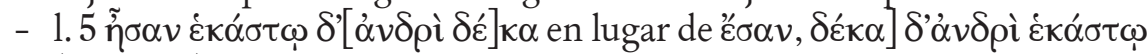
(Il. 2.618): actualización de la morfología verbal y orden de palabras normal en prosa en vez de hipérbaton.

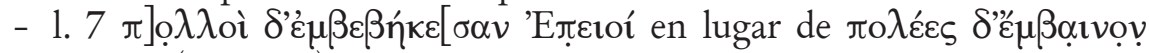

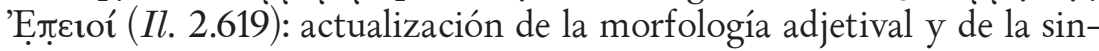
taxis verbal, utilizando el pluscuamperfecto, más preciso, en vez del épico imperfecto.

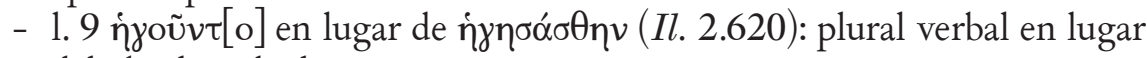
del obsoleto dual.

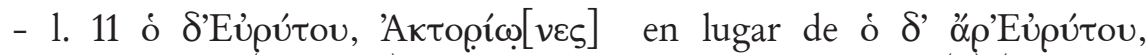

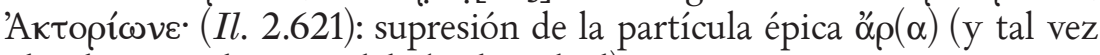
plural nominal en vez del obsoleto dual).

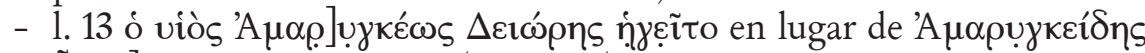

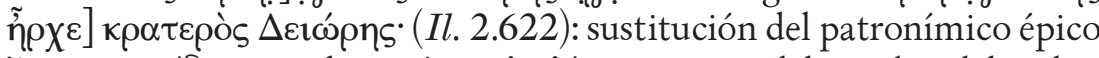
'A $\mu \alpha \rho$ orden de palabras normal en prosa frente al hipérbaton y sustitución,

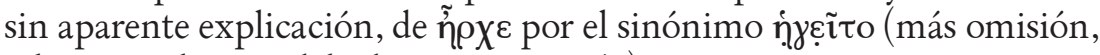

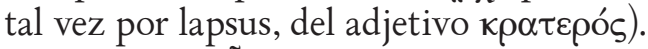

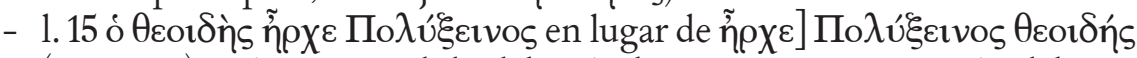
(Il. 2.623): epíteto precedido del artículo, aparente trasposición del verbo para evitar hiato con o y trasposición del sustantivo para dejarlo lo más cerca posible de la aposición ó viòs...l. 17.

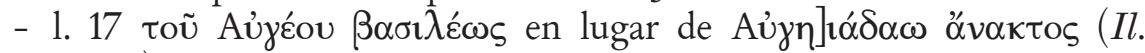
2.624): sustitución del patronímico por el giro ático de artículo + nombre del padre, y de la denominación épica del rey por la ática.

${ }^{22}$ Cf. V. Bartoletti, PSI 12 1276, 114, n. 1.

${ }^{23}$ Cf. V. Bartoletti, PSI 12 1276, 116. 


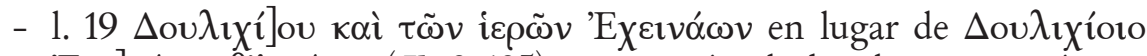
'EXi] vócov O'iepócov (Il. 2.625): aticización de las desinencias épicas

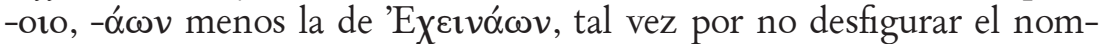
bre propio; introducción del artículo, sustitución de la conectiva épica $\theta^{\prime}(\tau \varepsilon)$ por la ática kaì y orden de palabras propio de la prosa en vez de

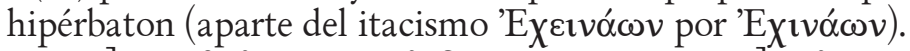

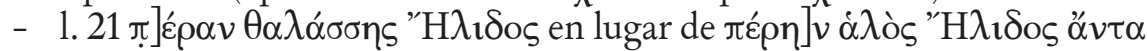

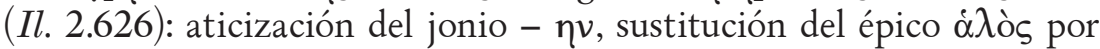

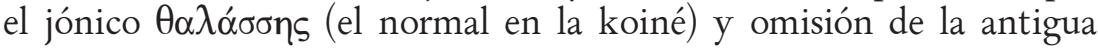
preposición en anástrofe $\alpha \dot{\alpha} \tau \tau \alpha$, aun cuando con ello ' $\mathrm{H} \lambda_{1} \delta$ os pasa a desempeñar otra función sintáctico-semántica.

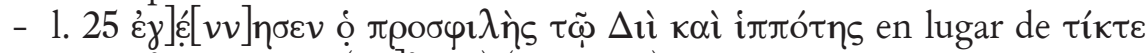

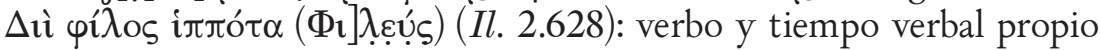

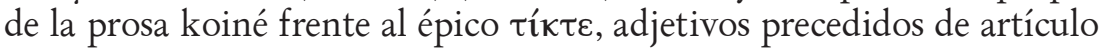
$\mathrm{y}$ adaptados igualmente a la prosa, sustantivo complemento adjetival precedido también del artículo y ambos adjetivos no en asíndeton sino coordinados con kaì según el uso prosístico.

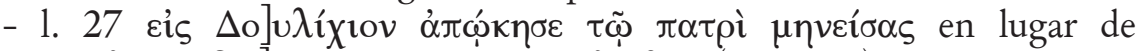

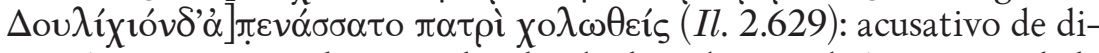
rección preposicional en vez de adverbial, verbos también propios de la prosa koiné en lugar de épicos (aunque $\mu$ nvíw es de origen homérico) y dativo complemento indirecto precedido del artículo en vez de sin él (aparte del itacismo $\mu \eta v \varepsilon i ́ \sigma \alpha \varsigma$ por $\mu \eta v i ́ \sigma \alpha \varsigma$ ).

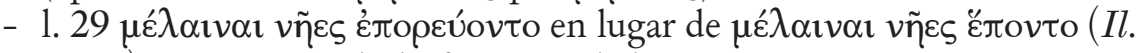

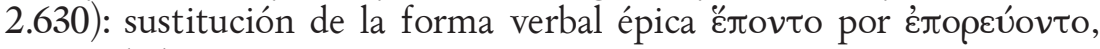
propia de la prosa.

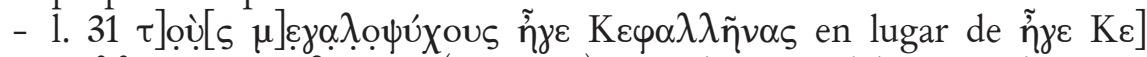

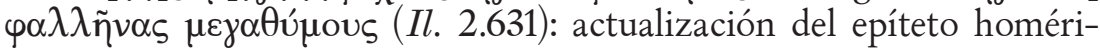
co al uso prosístico y precedencia del mismo por el artículo, y, como en 1.15, hipérbaton del verbo para crear ruptura estilística del enclave epíteto-sustantivo.

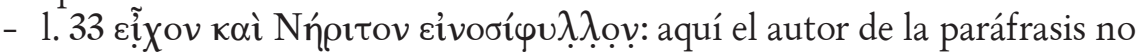
ha sabido encontrar un epíteto equivalente en su tiempo al homérico

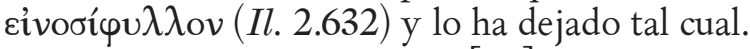

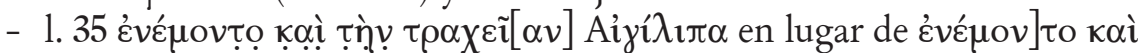

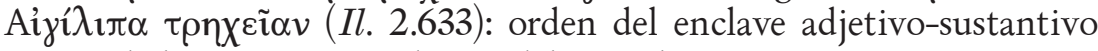
propio de la prosa y precedencia del artículo.

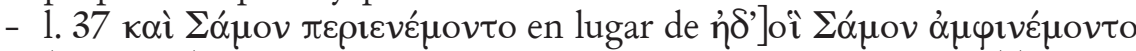

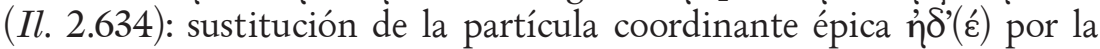
prosaica kaì, supresión del correlato épico oî̀ y sustitución de la forma

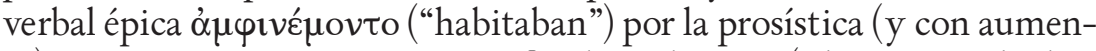
to) $\pi \varepsilon \rho \imath \varepsilon \varepsilon ́ \mu o v \tau o$, aunque su significado es distinto (Plut. Dio 46 lo dice del fuego que se extiende). 


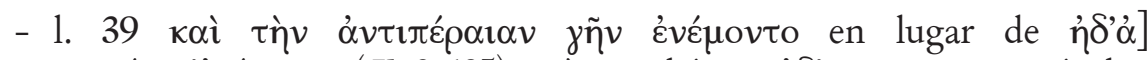

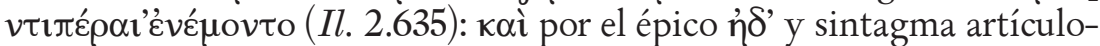
adjetivo-sustantivo propio de la prosa, con el adjetivo feminizado tal como aparece ya en la épica helenística y posterior, en lugar del neutro colectivo épico.

Si nos fijamos, las diversas manifestaciones de la técnica parafrástica del texto pueden resumirse ni más ni menos en su afán de adaptación, por la vía más directa posible, del lenguaje homérico a los usos morfológicos, léxicos, sintácticos y en algún caso estilísticos (cf. 1. 15, 31) característicos de la prosa de la koiné, con el fin de hacerlos perfectamente comprensibles para los lectores de la época. No se hallan, en cambio, indicios de que algunas de las soluciones adoptadas puedan proceder de escolios, como ocurre, por ejemplo, en el caso de la mencionada paráfrasis de Pselo, con expresiones como

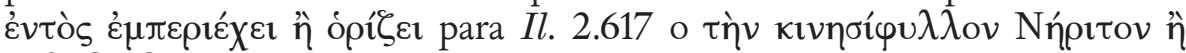
$\pi \mathrm{o} \lambda u ́ \delta \varepsilon v \delta \rho o v$ para $I l .2 .632$, donde por el contrario el autor de nuestra pará-

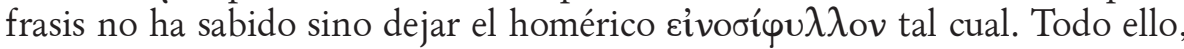
unido al carácter del pasaje, tan poco necesitado de paráfrasis en realidad, induce a pensar que el objetivo del ejercicio es puramente propedéutico y, si no escolar, al menos de carácter tan didáctico como podría serlo el ejercicio de un profesor para uso de los alumnos

El editor del papiro, lejos de considerarlo un texto escolar, supone que es parte de un texto más amplio, que podría incluir el poema entero, ofreciendo de él su paráfrasis verso por verso, como en el caso de las posteriores versiones de época bizantina ${ }^{24}$. Ahora bien, la evidencia con que contamos es que el texto conservado se limita al mencionado pasaje del Catálogo de las Naves, si bien es verdad que el cálculo de versos que faltan en el texto amplía un poco su número y el punto in medias res con el que coinciden tanto el principio como el final de estos permite conjeturar que la sección del canto incluida abarcaría por lo menos desde el v. 603 al v. 675. También sorprende que el texto parafraseado sea precisamente aquel que, dado el carácter sumamente esquemático, formulario y poco variado de cada una de las unidades que componen el $\mathrm{Ca}-$ tálogo, menos parece necesitarlo. De hecho, la mayoría de los manuscritos que transmiten las paráfrasis bizantinas de Homero mencionadas, suelen excluir esta parte del poema, sin duda por considerarla más fácil de seguir sin necesidad de parafrasearla ${ }^{25}$. Pues bien, al menos como conjetura quisiera lanzar la idea de que el contenido del rollo de papiro al que pertenece este fragmento bien pudiera reflejar la fase escolar perdida de este tipo de paráfrasis gramatical y de ahí que, al revés de lo que sucede con las paráfrasis bizantinas, destinadas a un público más abierto, atienda a una sección mucho más sencilla y adecuada para aplicar la propedéutica, cual es el monótono Catálogo de las Naves ${ }^{26}$.

${ }^{24}$ V. Bartoletti, PSI 12 1276, 115.

${ }^{25}$ Cf. V. Bartoletti, PSI 12 1276, n. 2, 33; Aegyptus 19, 1939, 183-4.

${ }^{26}$ La Suda menciona una metáfrasis del Catálogo obra de Triboniano, grammatikós de 


\section{P. Erl. 3, L.N. 5, recto}

Asignado al s. II d. C. y calificado de "a unique papyrus"27, de escritura claramente libresca aunque con tendencia a cursiva y con indicaciones de hablante, contiene, en la primera y única medio conservada de sus dos columnas, parte del debate de los dioses en Ilíada 1(528-48). Sin que pueda considerarse estrictamente gramatical, ya que no traduce el texto homérico palabra por palabra y verso a verso, lo sigue muy de cerca, al tiempo que muestra algunas coincidencias con la paráfrasis de M. Pselo.

Col. I

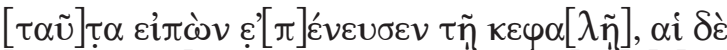

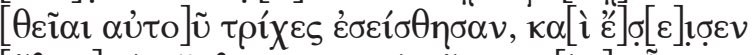

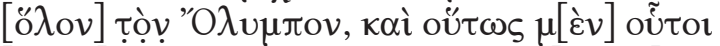

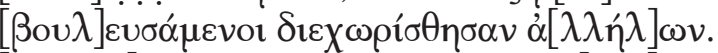

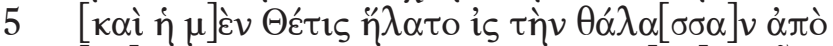

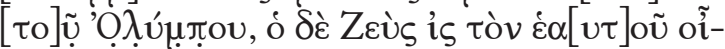

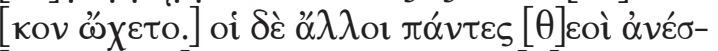

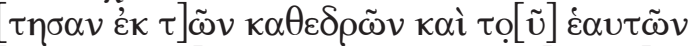

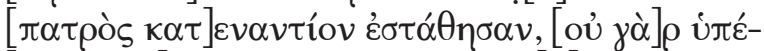

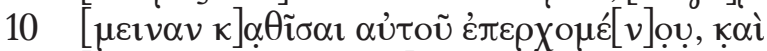

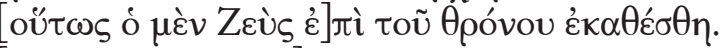

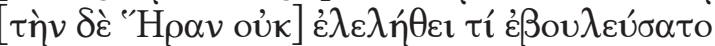

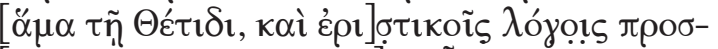

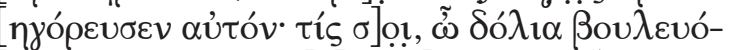

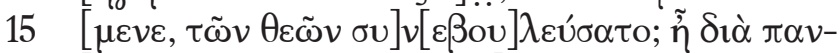

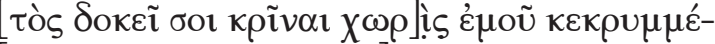

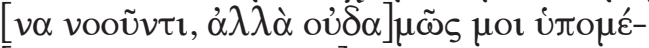

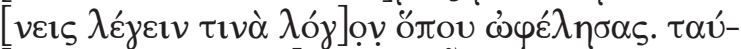

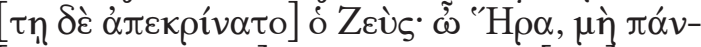

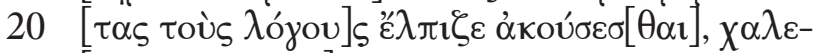

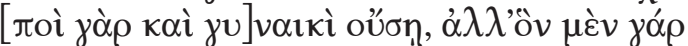

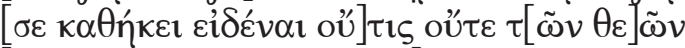

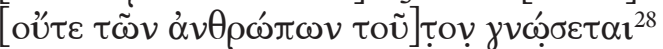

la época de Justiniano, cf. V. Bartoletti, Aegyptus 19, 1939, 184. Por otra parte, los catálogos figuran entre los elementos composicionales de los poemas homéricos particularmente apetecidos en la escuela, como instrumento que son para el aprendizaje de la geografía, el orgullo de pertenecer a una raza de nobles antepasados, etc., cf. R. Cribiore, "A Homeric Writing Exercise and Reading Homer in School," Tyche 9, 1994, 1-8.

${ }^{27}$ J. Spooner, Nine Homeric Papyri, 25, quien opta por explicar sus indicaciones de hablante, entre otras posibilidades y siguiendo la idea del editor de una probable adjudicación del ejercicio a la escuela de retórica, en el marco de "un contexto educativo" como posible preparación a la elaboración de discursos progimnasmáticos.

${ }^{28}$ Cf. Il. $1.528-48$

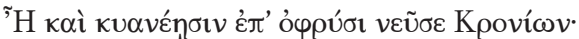

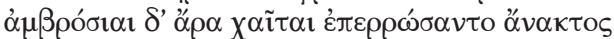


Bodleian Greek Inscription 3017 (LDAB 1844=Mertens-Pack 1176)

Tablilla de madera pintada de blanco, de $36,5 \times 13,5 \mathrm{~cm}$. y $6 \mathrm{~mm}$. de espesor, opistógrafa, procedente de la colección privada Sayce de Oxford, hoy en el Ashmolean Museum. Datada en s. II-III, contiene, en líneas pautadas en ambas caras y escrito con mano "rápida", de letras a veces separadas aunque manteniendo su forma cursiva ${ }^{29}$, en la cara 1: paráfrasis palabra por palabra de Il. 4.349-63 (airada réplica de Odiseo a Agamenón en el curso de su revista a las tropas y respuesta conciliadora de este), cada verso ocupando una línea y con vocabulario prosaico de la época en lugar del homérico; en la cara 2: Il. 4.364-73 (reprimenda ahora de Agamenón a Diomedes en el curso de dicha revista) ${ }^{30}$ y en la columna derecha glosario de 4.364-71. He aquí la paráfrasis: Bodl. Gr. Inscr. 3017, col. I

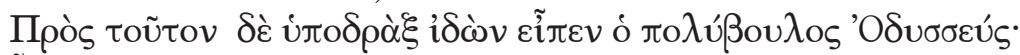

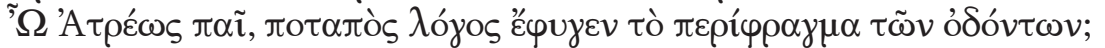

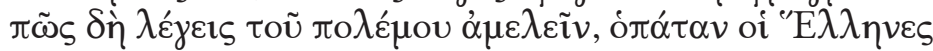

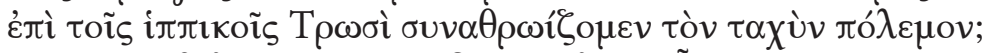

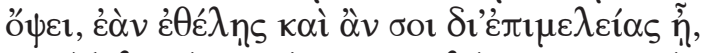

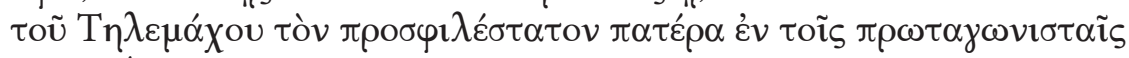

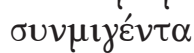

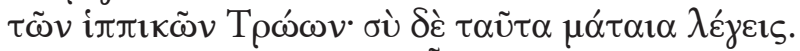

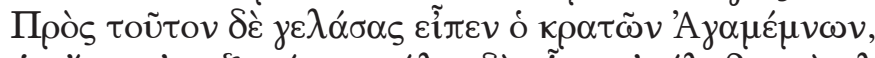

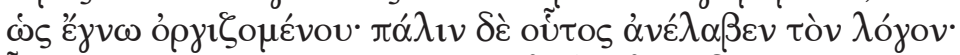

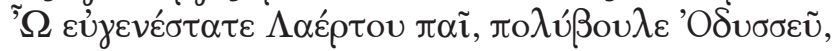

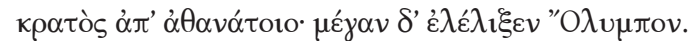

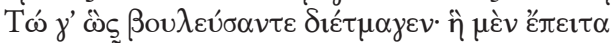

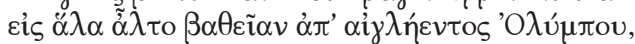

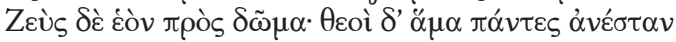

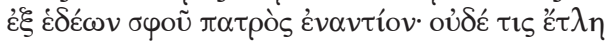

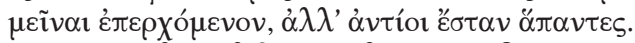

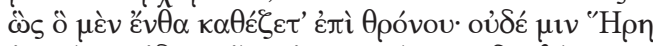

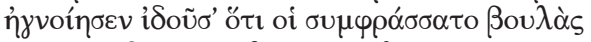

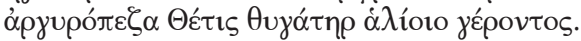

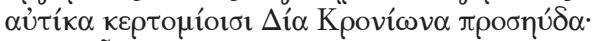

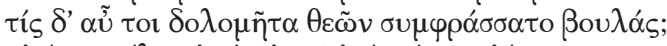

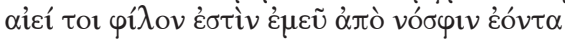

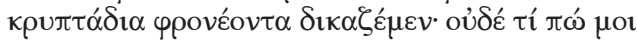

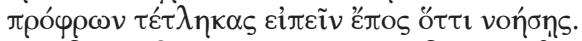

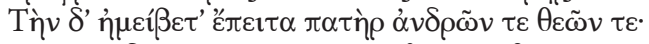

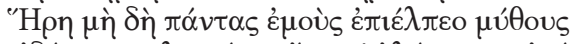

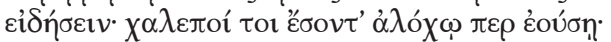

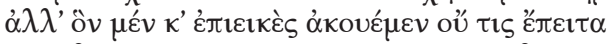

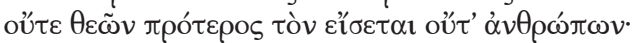

${ }^{29}$ R. Cribiore, Writing,Teachers, and Students in Graeco-Roman Egypt, American Studies in Papyrology, 36, Atlanta 1996, nº 333.

${ }^{30}$ Dicha revista militar constituye en definitiva una forma de catálogo, sobre cuyo papel en la escuela cf. supra n. 17 y 26. 


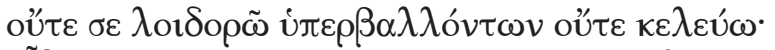

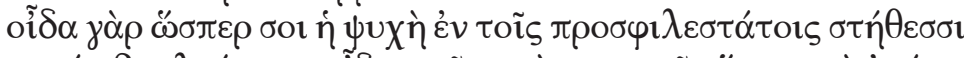

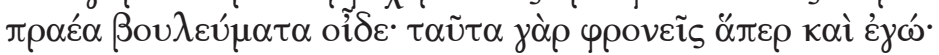

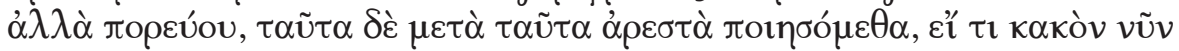

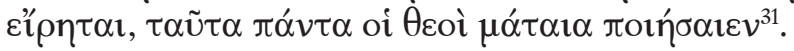

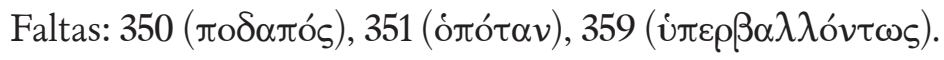

Los procedimientos parafrásticos son similares a los observados en $P S I$

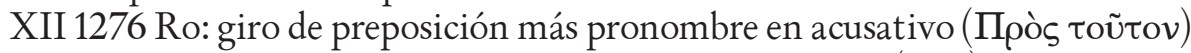
en lugar de artículo en acusativo en función pronominal (Tòv), supresión de

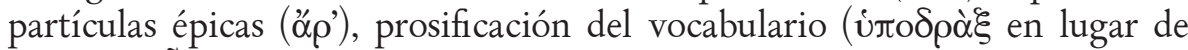
vं

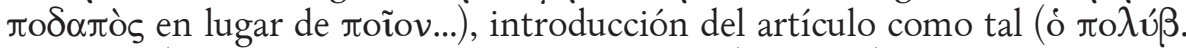

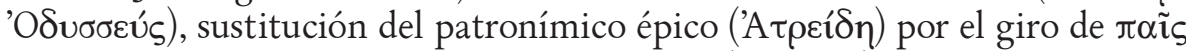

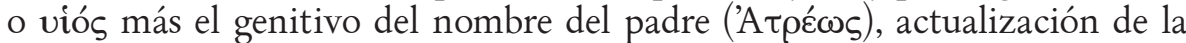

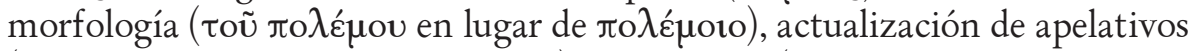

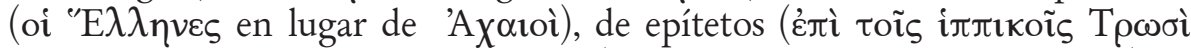

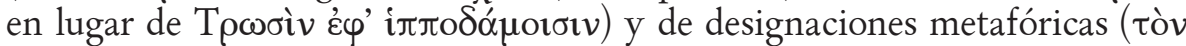

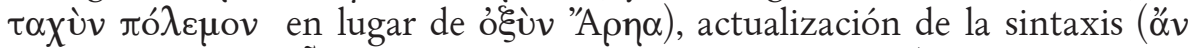

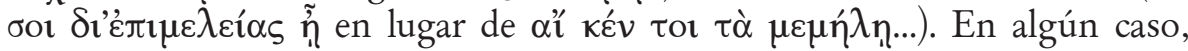
sin embargo, el parafraseador no dio con la palabra equivalente y dejó tal

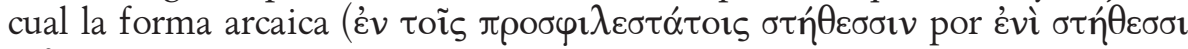

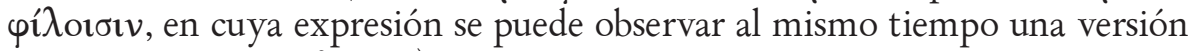

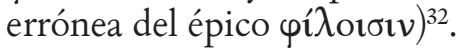

Hay toda una serie de coincidencias además entre las "traducciones" adoptadas por la presente paráfrasis y las adoptadas en los escolios de Dídimo y en la paráfrasis atribuida a M. Pselo, lo cual apunta sin duda a una tradición con-

${ }^{31}$ Cf. Il. $4.349-63$

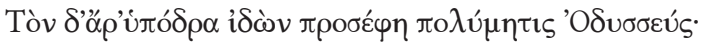

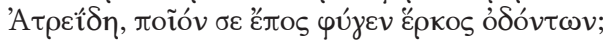

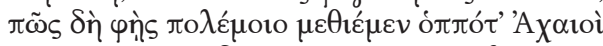

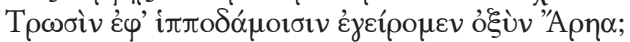

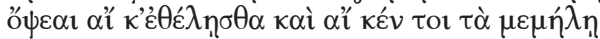

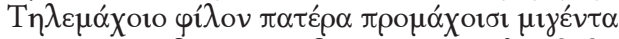

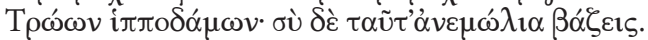

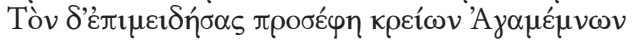

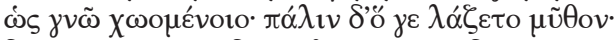

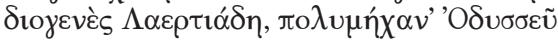

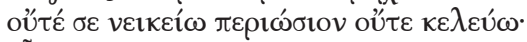

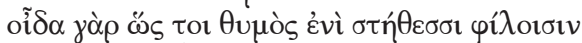

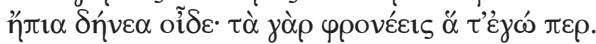

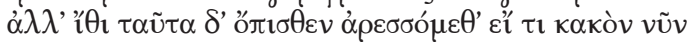

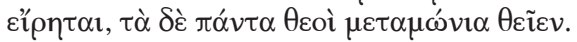

$32 \mathrm{Cf}$. nota siguiente. 
tinuada de material lexicográfico que se remonta ya a los scholia minora ${ }^{33}$. Sin embargo, tan significativos como los puntos de confluencia son los casos de divergencia, los cuales permiten pensar en un claro margen de individualidad por parte de cada uno de los parafraseadores.

Debido a las correspondencias que la presente paráfrasis muestra con los escolios de Dídimo y con la paráfrasis de M. Pselo los primeros editores la han considerado copia de un trabajo surgido de la escuela de Alejandría ${ }^{34}$. Pero, dada la presencia en la cara 2 de la tablilla de la copia del pasaje de Ilíada 4 que sigue al de la paráfrasis, acompañada del glosario que se necesitaría para parafrasear a su vez este, más acertado parece pensar en una conexión entre el contenido de ambas caras de la tablilla. El contenido de la cara 2 supondría la etapa preparatoria, es decir, la "búsqueda" del léxico de la koiné equivalente al del pasaje homérico en cuestión, para, en un posterior momento, llevar a cabo la suerte de "traducción" en que realmente consiste el tipo de paráfrasis llamado gramatical. El ámbito en el que se instala, pues, el ejercicio es la escuela, ya se trate de una copia escrituraria practicada por un alumno a fin de familiarizarse con la técnica o bien de una muestra de profesor, y su testimonio es importante para ilustrar algo que en otros casos imaginamos pero no podemos ver y es la relación existente entre los llamados scholia minora lexicográficos y la paráfrasis, en la misma etapa formativa de la escuela grie$\mathrm{ga}^{35}$. Dicha etapa es probablemente aquella que precede inmediatamente a la enseñanza progimnasmática, en varios de cuyos ejercicios y por sí misma la paráfrasis desempeña un papel muy importante ${ }^{36}$.

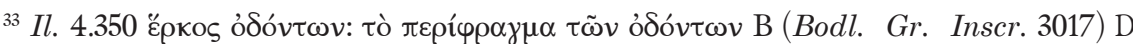

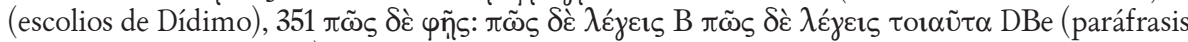

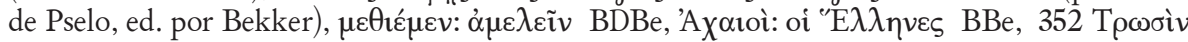

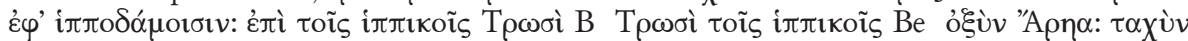

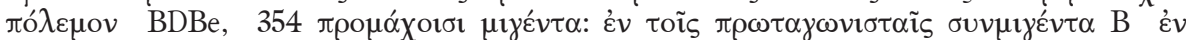

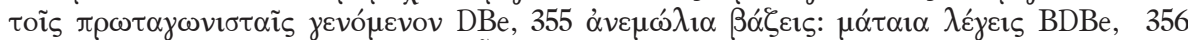

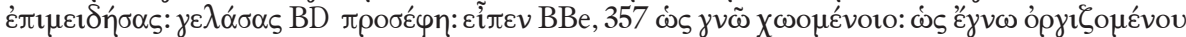

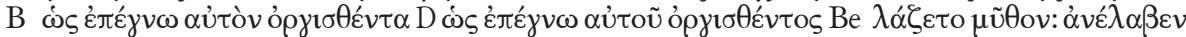

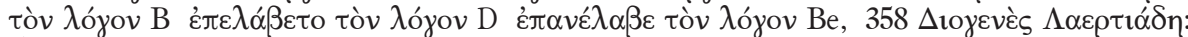

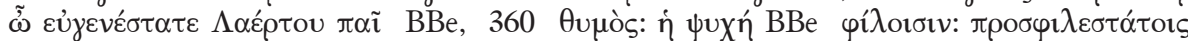

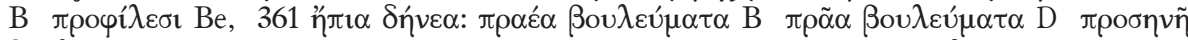

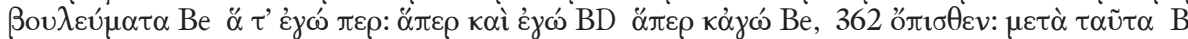

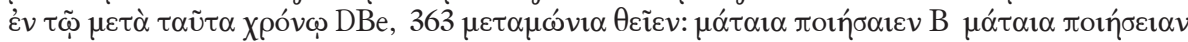

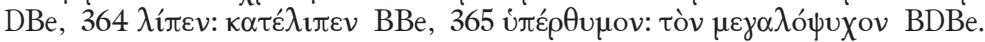

${ }^{34}$ M. Hombert \& C. Préaux, "Une tablette homérique de la Bibliothèque Bodléenne”, Mélanges Henri Grégoire 2, 1951, 161-8 (168).

${ }^{35}$ Cf. J. Spooner, Nine Homeric Papyri from Oxyrhynchos, Firenze 2002, 23-4.

${ }^{36} \mathrm{Cf}$. Theo 62, 10-64, $27 \mathrm{Sp}$. 
PSI II 135 (LDAB 1928=Mertens-Pack 1183)

La editio princeps del papiro (de $7 \times 7 \mathrm{~cm}$.) -datado por su editora ${ }^{37}$ entre los s. II-III d. C. y por los editores del CDRom Papiri Letterari della Biblioteca Medicea Laurenziana (Università degli Studi di Cassino, 2002) a mediados del s. II d. C.- lo califica de "fragmento mitológico", pensando solamente en el contenido del recto, en el que se habla (11. 4-10) de Licurgo, hijo de Driante, que maltrata a las nodrizas de Dioniso, esto es, las Ménades (1.

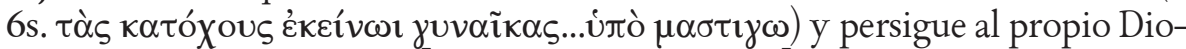

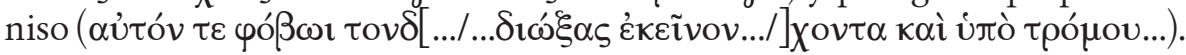
Aun siendo este el tema de Ilíada 6.130-40, el pasaje homérico es solamente mencionado por la edición como el primero de muchos otros testimonios. Del contenido del verso confiesa no saber a qué fin son referidas las palabras

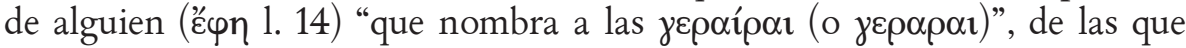
hablan el pseudodemosténico Contra Neera 59, 73ss. y sus comentaristas y lexicógrafos.

Ahora bien, los restos de doce líneas conservadas en el recto de la hoja de papiro contienen no solo los datos indicados en conexión con el pasaje de Ilíada 6.130-40, sino otros que a continuacion hablan de muerte de alguien (tal vez el transgresor: $\theta \nu \eta \sigma \kappa \eta ~ 1.12)$ y de los propios dioses $(\theta \varepsilon \tilde{\omega} v \alpha \dot{\tau} \tau \tilde{\omega}\{v\}$ 1. 11), al igual que lo hacen los versos 138-40 del pasaje homérico. También al

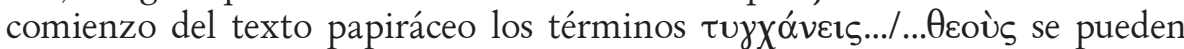

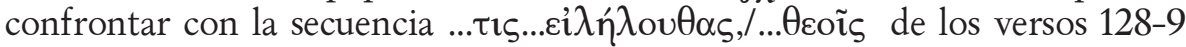
del pasaje iliádico, más allá de la idea generalizada en la bibliografía concerniente de que los versos confrontables de Ilíada VI son solamente 130-40. El argumento que los restos del texto papiráceo permiten rastrear y el pasaje de Ilíada 6.128-40 contiene, constituye el grueso de la primera interpelación que Diomedes dirige al troyano Glauco cuando se encuentran en la batalla: en vista del arrojo de Glauco, aquel le plantea la pregunta de si se trata de un ser divino, en cuyo caso Diomedes no piensa enfrentarse a él, al contrario de lo que hizo Licurgo, el hijo de Driante, acosando a las Ménades y persiguiendo al propio Dioniso, por lo cual fue castigado por los dioses y murió al poco tiempo ${ }^{38}$.

${ }^{37}$ T. Lodi, PSI II 135, 1913, p. 57

${ }^{38}$ Ilíada 6.128-40

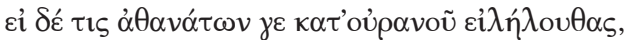

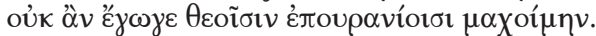

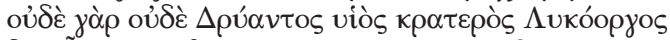

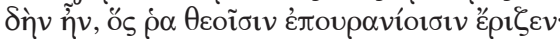

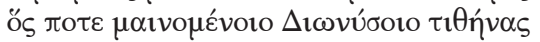

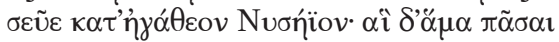

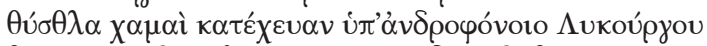

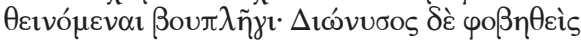

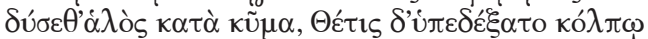

135

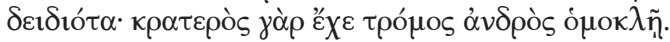


Un tipo de confrontabilidad similar se encuentra, como ha sido puesto de manifiesto en la edición de Wilamowitz del mismo año ${ }^{39}$, entre los restos de once líneas conservadas en el verso de la hoja de papiro y el pasaje de Ilíada 6.84-98, el cual contiene la sección principal de la interpelación dirigida por Héleno, el hijo de Príamo, a Héctor y Eneas instándoles a que animen a las tropas troyanas para que no se retiren del combate. De este modo, les dice en primera persona como lo hace Diomedes en el otro pasaje, nosotros resistiremos frente a los Dánaos; y a Héctor le encarga que vaya a la ciudad y le diga a su madre que reúna a las ancianas en el templo de Atenea llevando a la diosa el peplo más hermoso y estimado que tenga en palacio y le sacrifique doce novillas no uncidas, para que se apiade de las mujeres y sus hijos y aparte de Ilión al hijo de Tideo, el cruel guerrero, del que Héleno afirma que es el más fuerte de los Aqueos. Los términos y secuencias de términos que permiten identificar en el papiro el reflejo del texto iliádico son: $\pi \mathrm{o} \lambda \varepsilon \mu$ íous

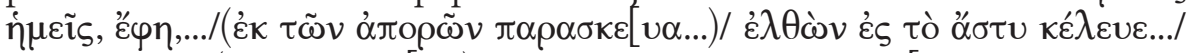

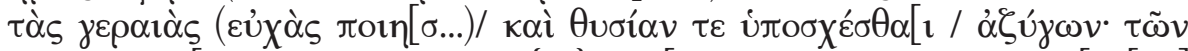

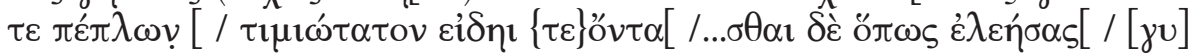

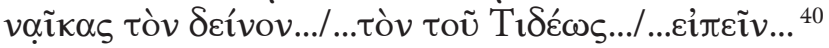

Tanto en el texto del recto del papiro como en el del verso, algunos de los términos de que constan coinciden con otros del respectivo texto iliádico:

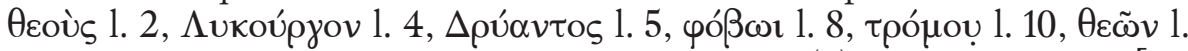

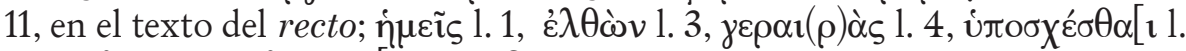

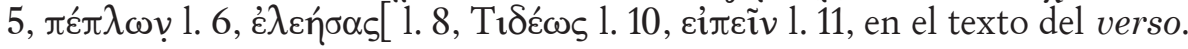

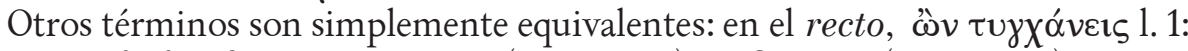

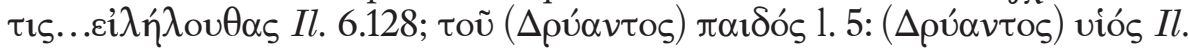

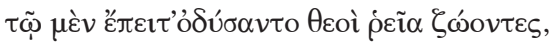

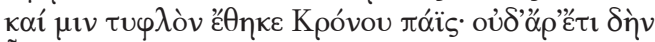

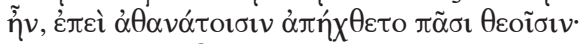

39 "Neue Veröffentlichungen der Italienischen Gesellschaft für Papyrusforschung”, Deutsche Literaturzeitung 34, 1913, 1863.

${ }^{40}$ Ilíada 6.84-98

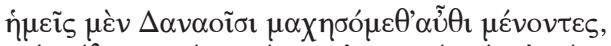

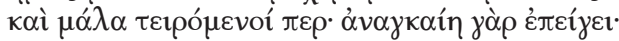

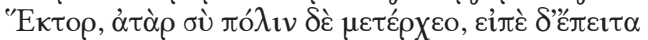

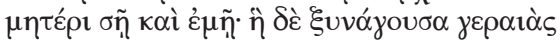

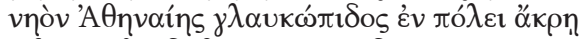

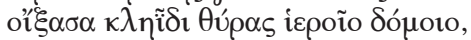

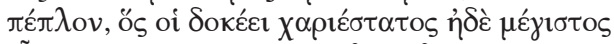

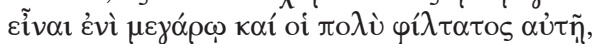

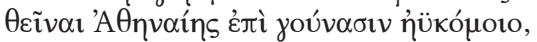

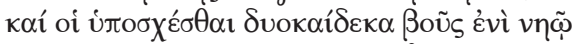

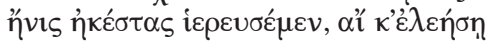

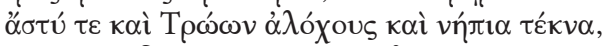

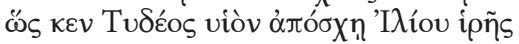

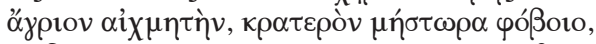

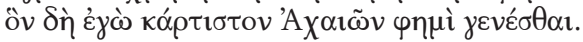




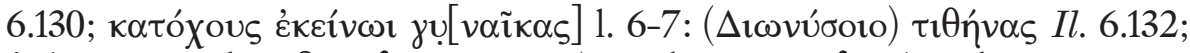

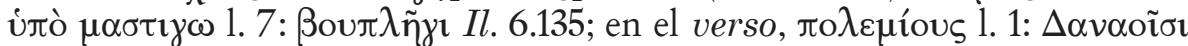

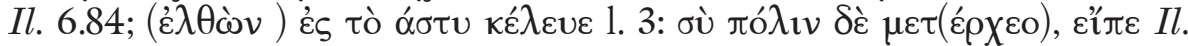

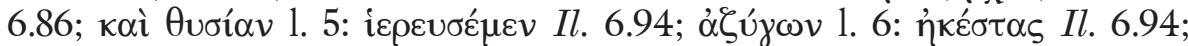

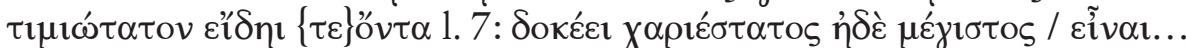

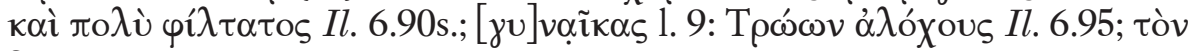
Szívov 1. 9: áypiov $\mathrm{Il}$. 6.97. Solamente unas pocas secuencias de términos del texto papiráceo no encuentran correspondencia en los respectivos pasajes iliádicos o bien esta es difícil de establecer ${ }^{41}$. El propio orden de sucesión de los términos o expresiones del papiro coincide básicamente con el de sus homólogos en los respectivos pasajes de $\mathrm{Il}$. 6, con la salvedad del trastrue-

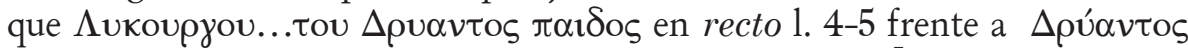

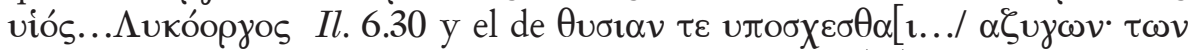

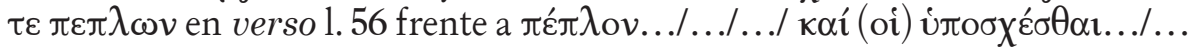

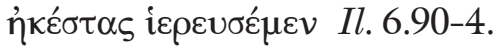

Por el contrario, frente al muy escaso interés expansivo mostrado por el texto del papiro, tanto el uno como el otro pasaje de Ilíada 6 añaden algunos otros pequeños contenidos a aquellos que encuentran correspondencia en el texto papiráceo, como indica, sin ir más lejos, la extensión que ocupan cada uno de los respectivos textos, a saber, 13 y 12 líneas de 30 letras recto y verso del papiro respectivamente, frente a $13(\mathrm{Il}$. 6.128-40) y 15 (Il. 6.84-98) hexámetros (de bastante más de 30 letras de promedio). En Il. 6.128-40 los elementos claramente excedentes con respecto al texto del papiro son: los que refieren el acoso de las Ménades por parte de Licurgo en el monte Niseo y la rendición de sus tirsos a tierra (v. 133s.), y luego la acogida de Dioniso por parte de Tetis (v. 136) y la especificación del castigo de Licurgo por Zeus como ceguera (v. 139s.). En $I l$. 6.85-98 tales elementos, si excluimos el v. 85 como supuesta matriz de la 1.2 verso del papiro, serían: la acción de abrir la puerta del templo de Atenea (para proceder a la ofrenda) (v. 89), la triple calificación superlativa del

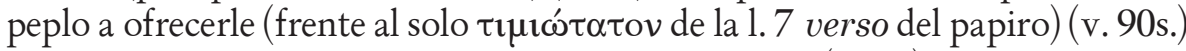
y la acumulación de rasgos caracterizadores de Tideo (v. 97). De todos ellos es probablemente la descripción del peplo ofrenda a Atenea (v. 90s.), con triple

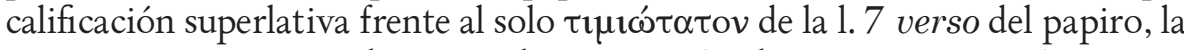
que mejor permite ver el proceso de contracción al que es casi sistemáticamente sometida la adaptación del texto iliádico en la versión papirácea, al menos en la medida en que el texto conservado permite vislumbrarlo.

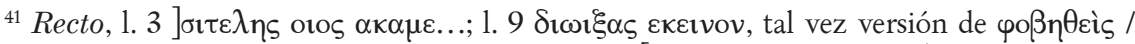

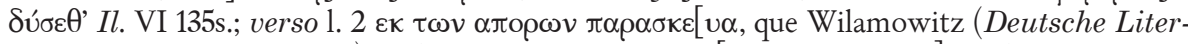

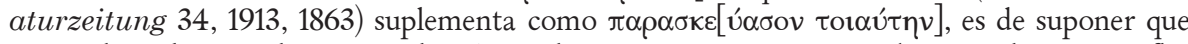
pensando en la segunda persona de Héctor, de $I l$.6.86ss., pero que muy bien puede querer refle-

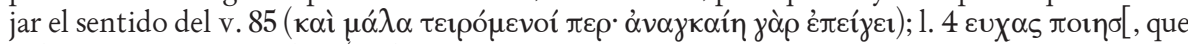
es la única expansión clara (Wilamowitz, Deutsche Literaturzeitung 34, 1913, 1863 suplemen-

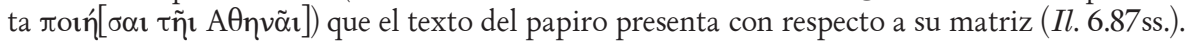


De lo que no parece que deba caber $\mathrm{duda}^{42}$ es de que el tipo de adaptación textual al que nos referimos es una de las formas que puede adoptar la paráfrasis. En este caso no se trata desde luego del tipo de paráfrasis más explicativa, ni siquiera de aquel que tiende a verter cada verso en una línea, sino de un tipo un poco más sintético, que trata de verter el contenido fundamental del texto fuente y prescindir de detalles no esenciales, si bien la ausencia del comienzo de cada verso iliádico en el recto del papiro y de su final en el verso papiráceo tal vez nos impida ver las cosas más claramente. Así, el texto del recto parece omitir el contenido de los versos 133-4 del citado pasaje de $I l .6$, los cuales añaden al dato esencial de la matanza de las Ménades por Licurgo los detalles del lugar donde este las hostigaba y la actitud de ellas al morir, y también el verso 139, el cual añade el detalle de la ceguera de Licurgo por obra de Zeus dentro de la indignación que el conjunto de los dioses manifestó contra él. Por el contrario, la única línea de este texto del papiro que podría suponer un añadido con respecto al texto fuente es la línea 3 , de la cual ya hemos dicho que no se ve el equivalente en aquel. La distribución de los nombres de Licurgo y Driante -por cierto, expresados en orden inverso y más lógico desde el punto de vista de su protagonismo en la acción- en dos líneas (4-5) en vez de una como en $I l .6 .130$, no supone expansión del original habida cuenta que la mención de ambos héroes en este se prolonga en un segundo verso (131) que refiere la acción de Licurgo y no parece encontrar equivalente en el papiro.

El texto del verso del papiro con respecto a $I l$. 6.84-98 parece omitir el v. 89, que contiene la acción, claramente expletiva por fácil de sobrentender, de, una vez en el templo de Atenea, abrir con su llave las puertas, y limitar a una sola línea (20) los dos versos de que consta la descripción del peplo, a base de

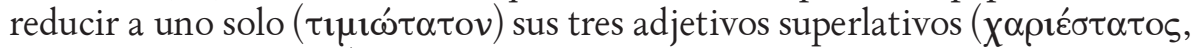

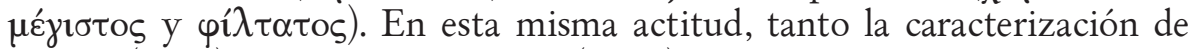
Atenea (v. 88) como la de Diomedes (v. 97), los dos principales elementos de referencia del texto iliádico, parece haber sido comprimida en sus términos (1. 17 y 22s. respectivamente). Por el contrario, la única expansión que en el

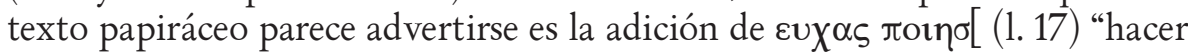
oración" precediendo a las otras dos acciones rituales coordinadas $\theta v \sigma t \alpha \nu \tau \varepsilon$ vло $\chi \chi \varepsilon \sigma \theta \alpha[$ "prometer un sacrificio" (1. 18) y ofrenda de un peplo (1. 19s.), acciones que, por otra parte, en el texto iliádico aparecen en el orden inverso: tal vez al autor de la paráfrasis le pareció más lógico comenzar el rito impetratorio por la oración, continuar con la promesa de sacrificio y culminarlo con la ofrenda del peplo, que hacer la ofrenda del peplo y luego la promesa del sacrifico como en el texto iliádico.

Los usos característicos de la lengua homérica son sustituidos en el papiro por términos y expresiones propios de la prosa ática o de la lengua de

${ }^{42}$ En contra de la todavía mostrada en un repertorio reciente cual es el CPP (Catalogue of Paraliterary Papyri, K. U. Leuven). 
la koiné, tal como es habitual en los ejercicios parafrásticos en general. Así,

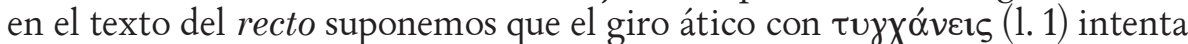

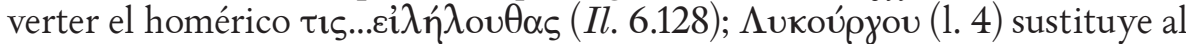

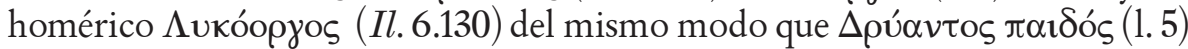

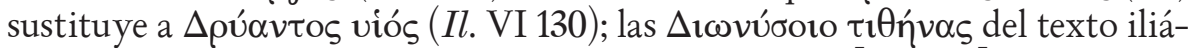

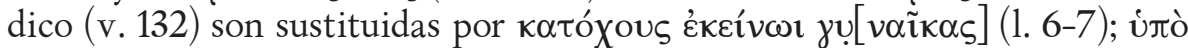
$\mu \alpha \sigma \tau \boldsymbol{\gamma} \tilde{\omega}\{1\}$ ? (1.7) parece querer verter el homérico ßov $\pi \lambda \tilde{\eta} \gamma \mathbf{l}(I l .6 .135)$; en el

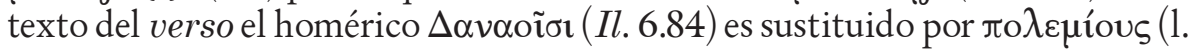

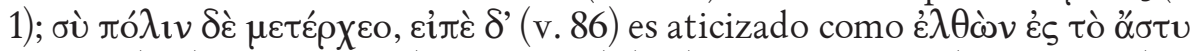

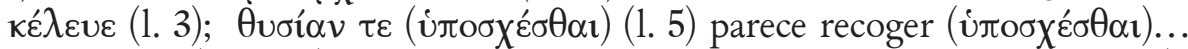
i

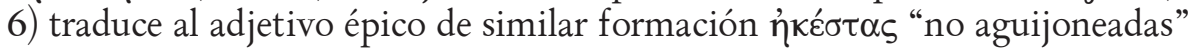
(v. 94) para referirse en ambos casos a las novillas destinadas al sacrificio; el homérico y poético ả $\lambda$ óxous (v. 95) es vertido simplemente como juvaĩkas

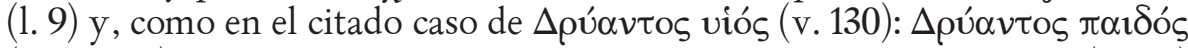
(recto 1. 5) para referirse al héroe Licurgo, el homérico Tudéos vióv (v. 96)

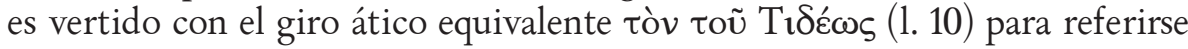
al héroe Diomedes. Si la presencia de algunos signos diacríticos y de lectura (parágraphos, dos espíritus ásperos, tres diéresis, varios puntos altos) puede hacer pensar en el trabajo de un profesor, el destino más probable del mismo debió de ser el servir de muestra a los alumnos para, como dice A. Körte ${ }^{43}$ en su breve pero sustanciosa reseña del papiro, "den Inhalt eines Stückes der Ilias mit andern Worten wiederzugeben".

Aparte de sus adaptaciones a la lengua literaria de la época, la doble paráfrasis homérica de PSI II 135 destaca por su economía expresiva y los principales cambios en la forma expositiva (el cambio de orden Licurgo-hijo de

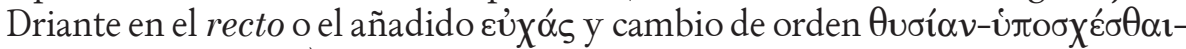
$\pi \varepsilon ́ \pi \lambda \omega v$ en el verso) parecen responder a un afán lógico y de racionalización. En cuanto al nexo que pueda haber entre ambos textos, según ya su editora se pregunta, más significativo que el hecho, apuntado por esta, de que las jepaıpaí áticas (cf. 1. 4 verso) sean adeptas del culto de Dioniso, que es la divinidad del exemplum mítico en el recto del papiro ${ }^{44}$, nos parece el hecho de que ambos textos homéricos son discursos directos, y como tales muy adecuados para su uso escolar ${ }^{45}$, en los que el héroe Diomedes es referente esencial; en el texto del recto porque él es quien habla, en el célebre discurso que dirige a Glauco en el combate, diciéndole que, si este es un ser divino, no va a enfrentarse a él como hizo Licurgo con Dioniso; en el texto del verso el hijo de Tideo (1.10) es el enemigo frente al cual Héleno envía a su hermano

${ }^{43}$ A. Körte, Archiv für Papyrusforschung 7, 1924, 245.

${ }^{44}$ No obstante, A. Carlini, "Su tre papiri omerici”, Zetesis (Festschrift De Strijcker), 1973,

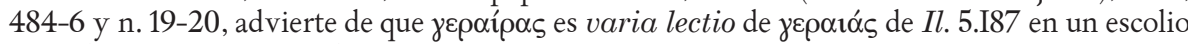
y en algunos manuscritos homéricos.

${ }^{45}$ Cf. A. Carlini, Zetesis (Festschrift De Strijcker), n. 17. 
Héctor a decir a las ancianas troyanas que hagan una ofrenda y prometan un sacrificio a Atenea para que se apiade de ellas y las libre del belicoso guerrero, "del cual proclamo que es el más fuerte de los Aqueos", termina la gradatio descriptiva de este que comienza en el verso anterior (v. 97-8). Precisamente esta, la del clímax referencial del héroe, puede ser tal vez la razón de que el autor de las dos paráfrasis haya llevado a cabo en primer lugar (recto) la del texto que en Ilíada (6.128-40) va después del texto parafraseado en el verso del papiro (Il. 6.84-98).

Bodleian Greek Inscription 3019 (LDAB 2418=Mertens-Pack 2732) Tablillas $1 \mathrm{~b}+4 \mathrm{a}$

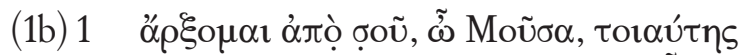

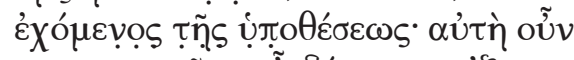

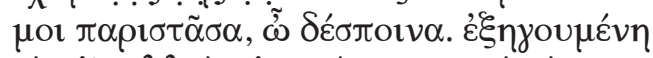

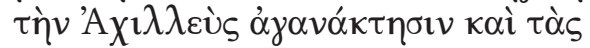

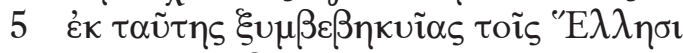

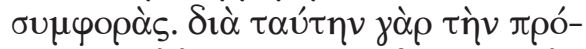

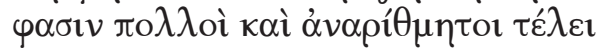

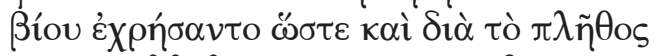

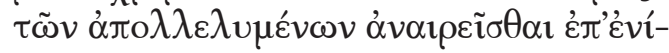

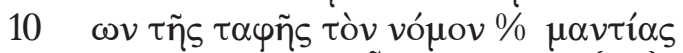

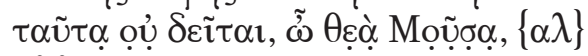

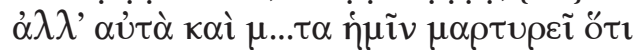

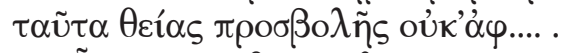

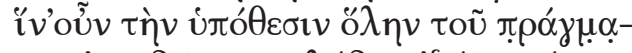

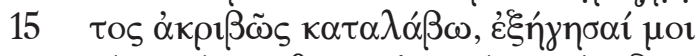

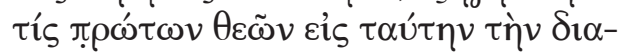

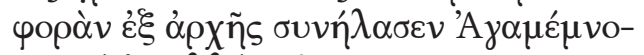

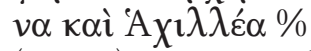

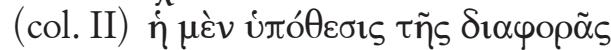

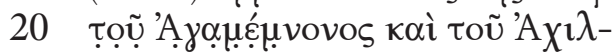

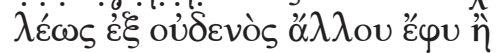

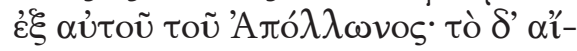

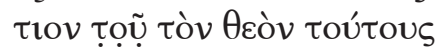

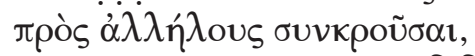

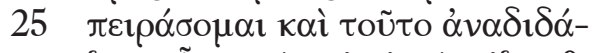

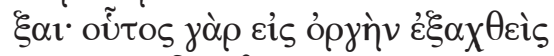

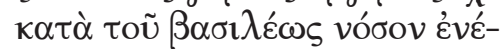

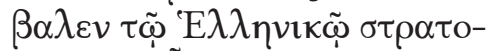

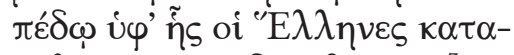

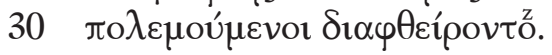

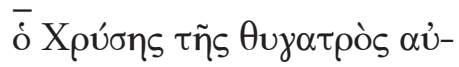




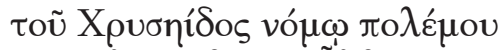

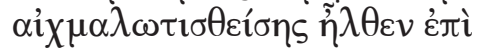

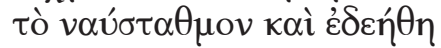

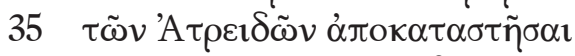

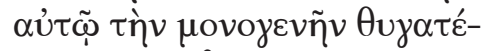

$\rho \alpha \tau 01 \alpha \tilde{v} \tau \alpha \lambda \varepsilon_{\gamma} \omega \nu$

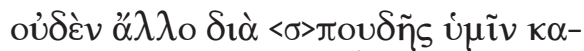

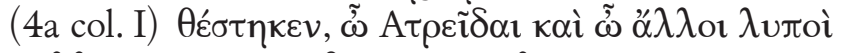

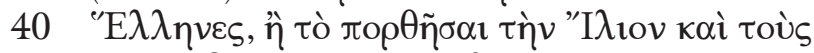

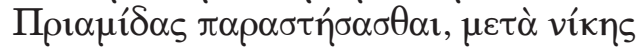

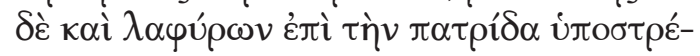

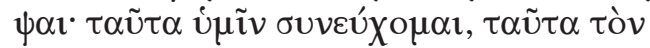

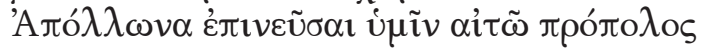

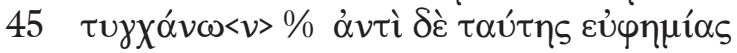

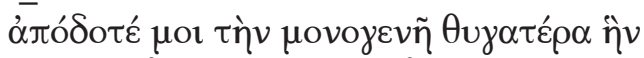

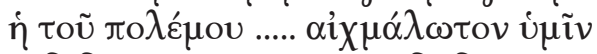

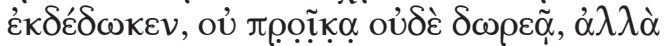

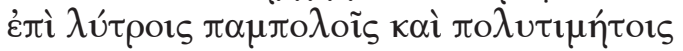

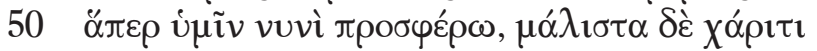

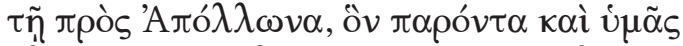

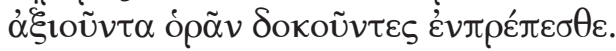

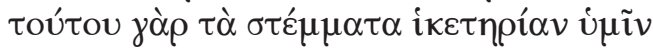

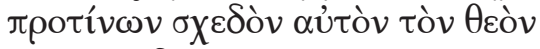

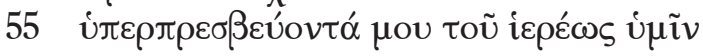
$\pi \alpha$

(col. II) oü $\tau \omega \varsigma \varepsilon \varepsilon \pi$

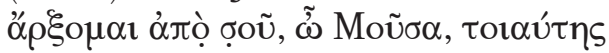

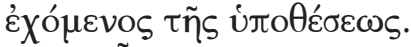

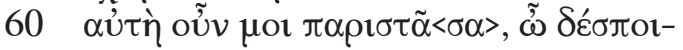
$v \alpha^{46}$

${ }^{46} \mathrm{Il} \cdot 1 \cdot 1-21$

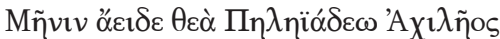

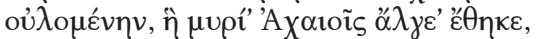

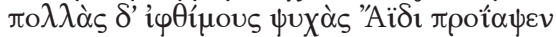

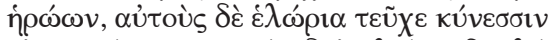

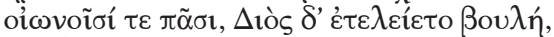

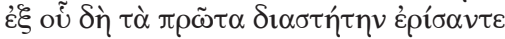

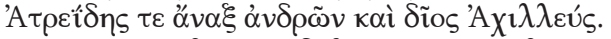

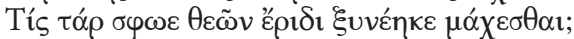

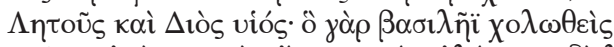

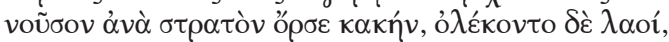

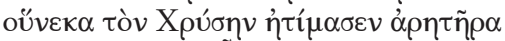

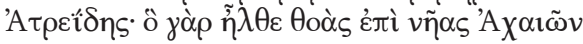


"Comenzaré por ti, Musa, al abordar tal historia. Asísteme tú, señora, y expón el enfado de Aquiles y las desgracias sobrevenidas a los Helenos por causa de ello.

Por este motivo, en efecto, muchos e innumerables hallaron el fin de la muerte, de modo que por la multitud de muertos se suprimió en ocasiones el rito del enterramiento. Esto no requiere dotes mánticas, divina Musa, sino que por sí solo... nos atestigua que ello es cosa de un ataque divino, no de... A fin, pues, de que yo entienda exactamente el contenido entero del asunto, explícame cuál de los dioses empujó el primero desde el principio a Agamenón y a Aquiles a esta disputa.

La historia de la disputa entre Agamenón y Aquiles de nadie más surgió que del propio Apolo; y la causa de que el dios enfrentara a aquellos entre sí intentaré también explicarla. Llevado este de la ira contra el rey hizo surgir una peste en el ejército helénico, atacados por la cual perecían los Helenos. Crises, habiendo sido hecha prisionera su hija Criseida según las normas de la guerra, se dirigió al campamento y pidió a los Atridas que le devolvieran a su única hija, con estas palabras:

Ninguna otra cosa ansiáis más, Atridas y demás Helenos, que destuir Ilión y quitar de enmedio a los Priamidas, y regresar a vuestra patria con la victoria y los despojos. Eso ruego con vosotros, eso pido a A polo que os conceda, como servidor suyo que soy. Mas a cambio de esta oración devolvedme a mi hija unigénita, a la que la...de la guerra os ha entregado como prisionera, no gratuitamente ni como regalo, sino mediante un muy cuantioso y costoso rescate que aquí os traigo, y más que nada en gracia a Apolo, al cual debéis respetar en la creencia de que está presente y tiene a bien que lo veáis; pues me presento ante vosotros ostentando las ínfulas de aquel en señal de súplica cual si fuera el dios en persona en honor a mí su sacerdote.

Así $\operatorname{dij}(o)$.

Comenzaré por tí, Musa, al abordar tal historia. Asísteme tú, señora”

La presente paráfrasis forma parte de un "school-book" o códice escolar, fechado en el s. III, que perteneció a la colección Sayce de Oxford, hoy en el Ashmolean Museum, y está constituido por siete tablillas de madera, de unos 11 x 23, $8 \mathrm{~cm}$. y 2-3 mm. de espesor excepto la última, que es la cubierta. Además de este texto contienen: una lista de pronombres declinados, tablas de

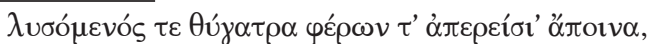

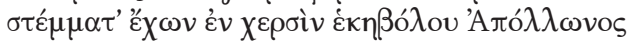

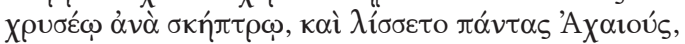

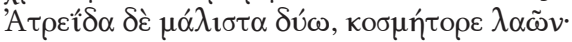

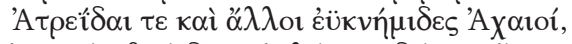

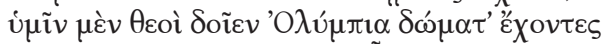

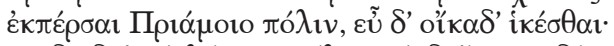

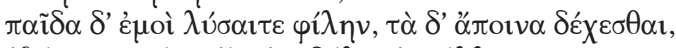

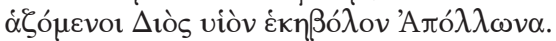


fracciones, declinación de una chreia, conjugación del paradigma de đotéco y dos salmos en copto (046.3-10).

"Elaborada reescritura retórica", en palabras de su editor, P. Parsons ${ }^{47}$, del comienzo de la Ilíada (vv. 1-21), corresponde a un bien conocido tipo de ejercicio literario ${ }^{48}$, perteneciendo a aquel de los dos grandes tipos de paráfrasis que constituye no un medio de comprensión sin más del texto parafraseado, sino un fin en sí mismo y un producto literario autónomo ${ }^{49}$. Dentro de la llamada paráfrasis retórica, no obstante, la presente muestra sobrepasa con mucho en grado de elaboración a cualquier otra de las paráfrasis homéricas conservadas en papiro. Dicha elaboración consiste, en primer lugar, en una serie de añadidos con respecto al texto original los cuales pueden adoptar distintas funciones. De enfático podemos calificar el añadido que, precediendo al comienzo del argumento del texto iliádico parafraseado, declara empezar su

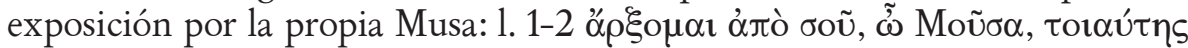

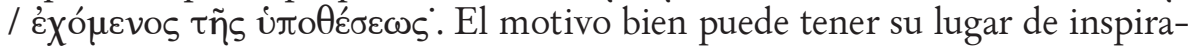
ción en un pasaje como el del conocido proemio de la Teogonía hesiódica, v. 1. Otros añadidos, situados al comienzo de las frases que respectivamente encabezan, tienen por objeto concatenar de forma lógica las partes del discurso que el poema épico presenta simplemente yuxtapuestas, aportando así

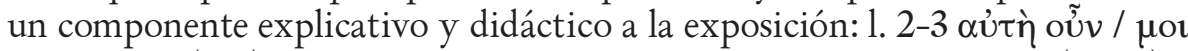

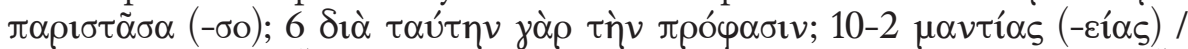

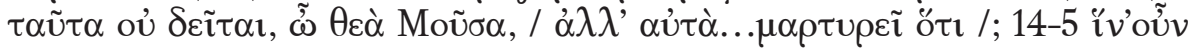

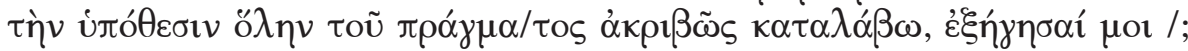

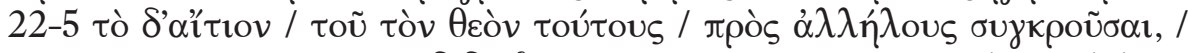

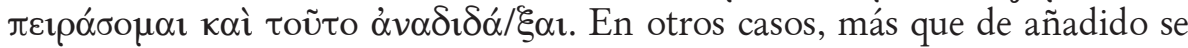
trata de una expansión del relato homérico que trata de explicar lo que este sobrentiende, estirándolo hasta el doble de sus dimensiones: 1. 26-30 oũ

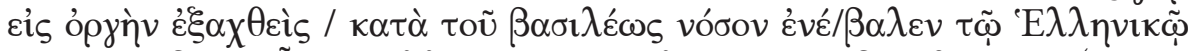
$\sigma \tau \rho \alpha \tau o / \pi \varepsilon \dot{\delta} \omega$ í $\varphi$ '

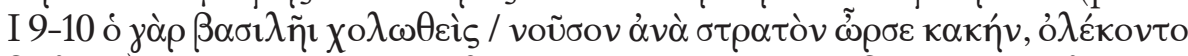

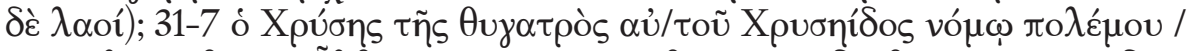

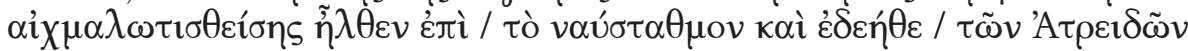

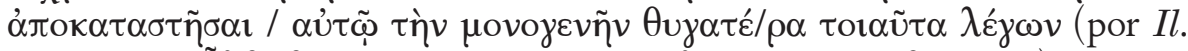

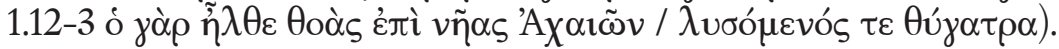

Esta técnica de la expansión explicativa se hace particularmente notoria en la elaboración parafrástica de la intervención de Crises en primera persona, con la cual termina el pasaje homérico y que de los cinco versos que ocupa

${ }^{47}$ ZPE 6, 1970, 133-49 (138). Cf. R. Cribiore, Writing, n 388; L. del Corso, "Libri di scuola e sussidi didattici nel mondo antico", en L. del Corso \& O. Pecere (eds.), Libri di scuola e pratiche didattiche dall'Antichità al Rinascimento (Atti del Covegno Internazionale di Studi, Cassino, 7-10 Maggio 2008), Università di Cassino 2010, 71-110 (82-4).

${ }^{48}$ Cf. K. Lehrs, Die Pindarscholien, 50.

${ }^{49}$ Cf. Quint. Inst. 10.5.5. 
en este pasa a alcanzar 19 líneas en la paráfrasis y la entidad de un verdadero discurso. No obstante, los puntos de que consta su argumentación pueden reducirse in nuce a las tres exhortaciones a los Aqueos que conforman la intervención iliádica de Crises y en el mismo orden, con una sola salvedad de la que luego hablaremos. Dichas exhortaciones instan: a que los dioses les concedan destruir la ciudad de Príamo y regresar con bien a casa, a que le devuelvan a su hija y a que acepten el rescate al tiempo que veneran a $\mathrm{Apolo}^{50}$. La diferencia de extensión en su tratamiento es ocupada una vez más por el añadido de nexos lógicos entre las secciones del discurso, por el desdoblamiento de conceptos y por la explicación de detalles que en el texto iliádico se dejan sobrentender, de modo que resulta mucho más patente la típica concatenación do ut des entre los tres mencionados componentes discursivos de: ruego por el regreso victorioso de los griegos, ahora centrado exclusivamente en Apolo, al margen de los demás dioses; petición de la devolución de su hija a cambio; y oferta de un generoso rescate además del agradecimiento de Apolo a través de su representante ${ }^{51}$. El único añadido sustancial en la paráfrasis lo constituye la última frase del tercer punto argumentativo y del texto en general, sobre la identificación del dios con su representante el sacerdote, la cual no es en realidad nueva con respecto al texto iliádico, sino traslado del concepto presente

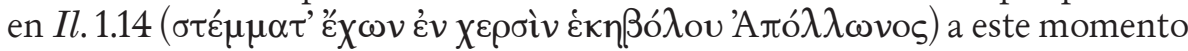
cenital de la coronación del ejercicio.

Frente a los abundantes añadidos y expansiones se observa en la paráfrasis un par de supresiones, las cuales parecen tener que ver con otro aspecto de la misma que es su innegable afán de actualización del relato no solo desde el punto de vista de la lengua y el estilo, sino también de acuerdo con los usos y costumbres de la propia época del ejercicio y no de la época homérica. Una es la supresión, en la frase que acabamos de señalar, del equivalente de

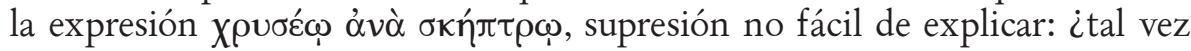
porque la mención del cetro parecía poco oportuna en manos de quien va a suplicar a otro posesor natural de cetro cual es el rey?. Otra es la supresión del

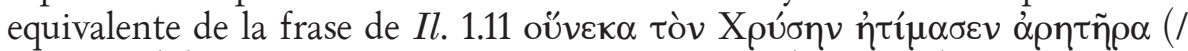

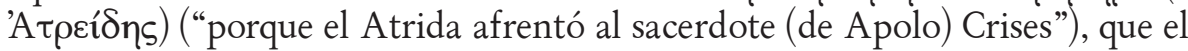

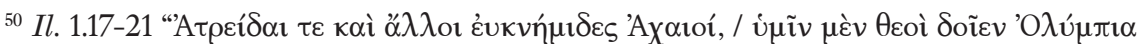

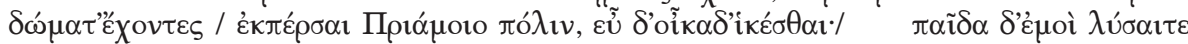

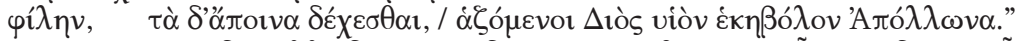

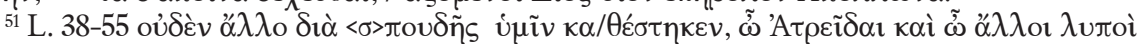

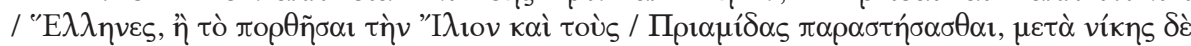

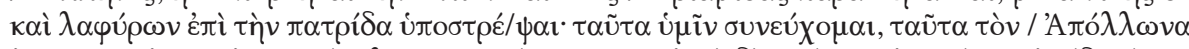

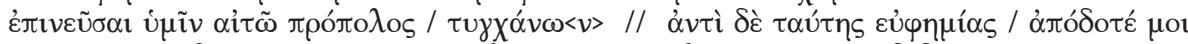

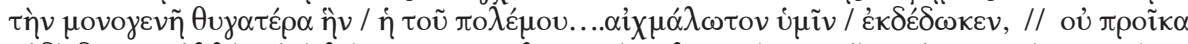

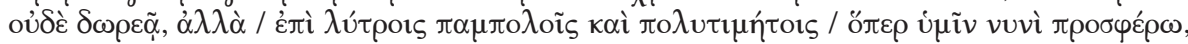

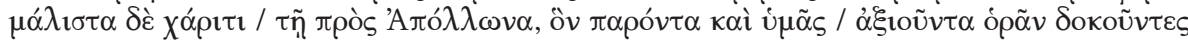

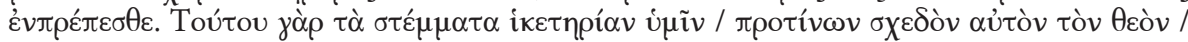

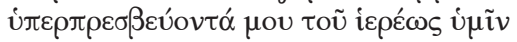


relato homérico da como causa del envío de la peste por parte de Apolo y que al autor de la paráfrasis probablemente le pareció una mención poco edificante a juzgar por la eufemística explicación que a su vez sugiere para el sojuzga-

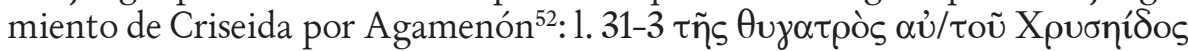

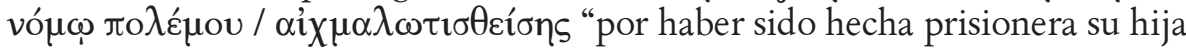
Criseida de acuerdo con las normas de la guerra", repetida de nuevo en 1. 46-8

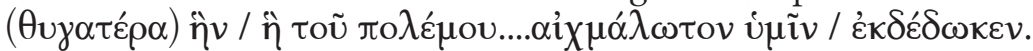

En esta misma línea de intentar suavizar los detalles más crudos del mito

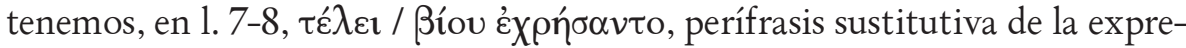

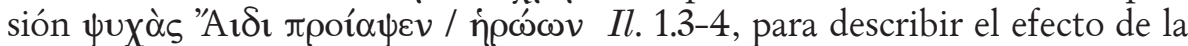

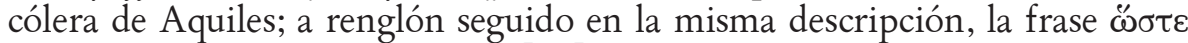

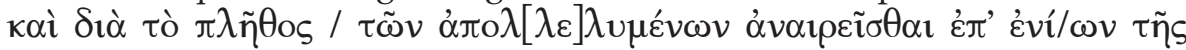
$\tau \alpha \varphi \tilde{n} s$ tòv vónov "hasta el punto de que, debido al número de muertos, se suprimió el rito del enterramiento en algunos casos" $1.8-10^{53}$, sustitutiva de la

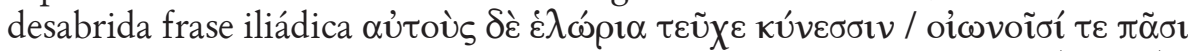
Il. 1.4-5, o a continuación la sustitución de la "voluntad de Zeus" $(\Delta$ iòs $(\delta$ '

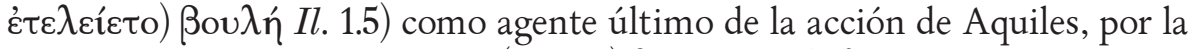
expresión menos personalizada ( $\tau \alpha \tilde{v} \tau \alpha) \theta \varepsilon i ́ \alpha \varsigma \pi \rho \circ \beta \beta \mathrm{o} \lambda \tilde{\eta} \varsigma$ 1. 13. Al propósito de presentar a los protagonistas del mito de la manera más clara y directa obedece sin duda la supresión sistemática de los típicos epítetos homéricos o

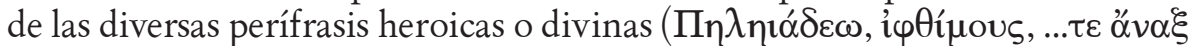

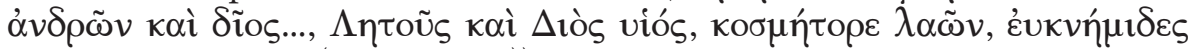

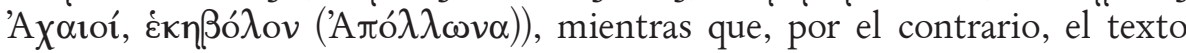
no duda en acompañar la doble mención de la hija de Crises de un epíteto,

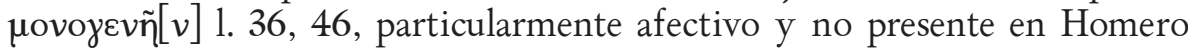
pero sí ya en Hesíodo y luego en la historia posterior de la lengua griega.

Instrumento esencial de la claridad de expresión es el tipo de sintaxis utilizada, que podemos calificar de analítica no solo por el empleo sistemático del artículo, sino por desglosar a veces conceptos que en el pasaje homéri-

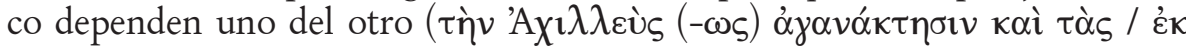

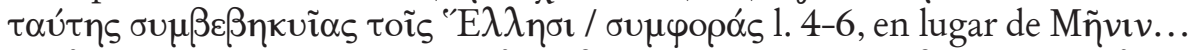

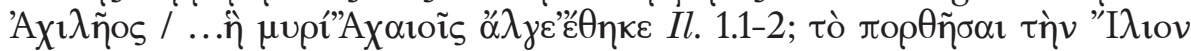

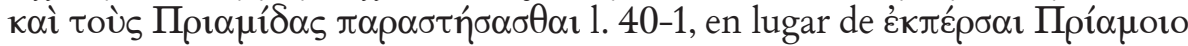

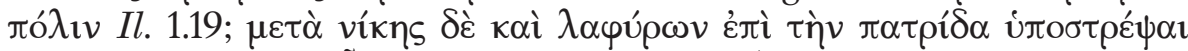

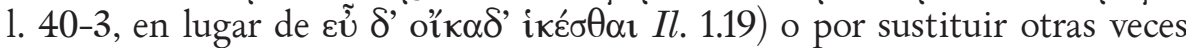
oraciones coordinadas o yuxtapuestas por las subordinadas a las que semánti-

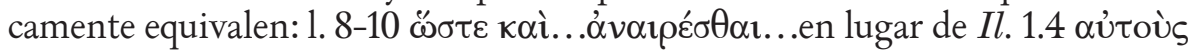

${ }^{52}$ Menos probable nos parece la explicación de Parsons (141) de considerarla una omisión del escriba, habida cuenta además que entre 1.30 y 31 hay una parágraphos divisoria, lo cual obligaría al escriba a prestar más atención.

${ }^{53}$ Parsons 141 n. 22 hace suya la sugerencia de Russell de que esta frase puede hacer alusión al conocido pasaje de Tucídides 2.52 vó

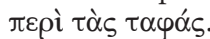




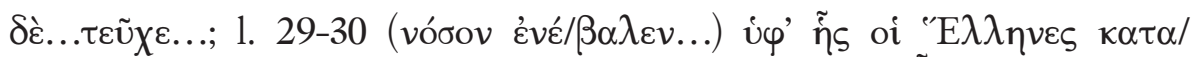

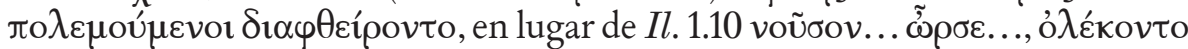
$\delta \varepsilon \grave{\lambda} \lambda \alpha o$. En ocasiones el afán de claridad es retóricamente forzado a través del

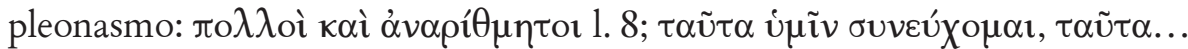

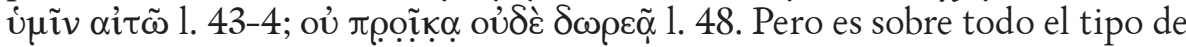
vocabulario utilizado, el habitual en la prosa de la koiné, el que contribuye a hacer de esta paráfrasis una especie de versión del correspondiente pasaje iliádico apta no solo para sustituirlo sino hasta para medirse con él ante los lectores de su tiempo, empezando por el ámbito escolar: vं prosaico y propio de la crítica literaria en el sentido que aquí tiene de tema de

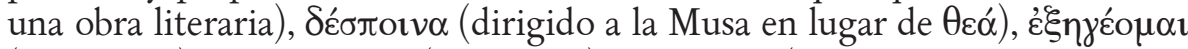

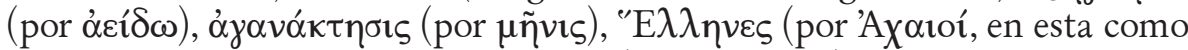

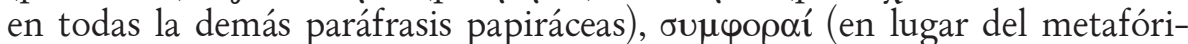

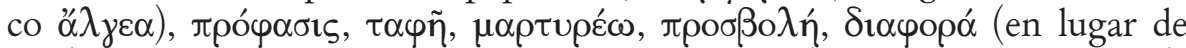

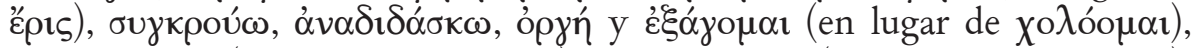

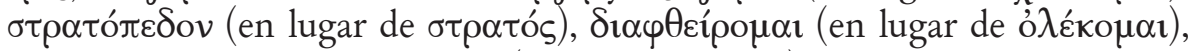

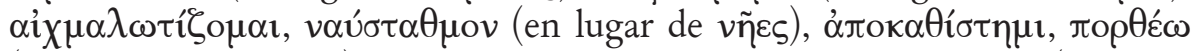

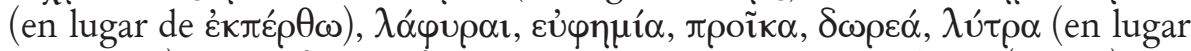

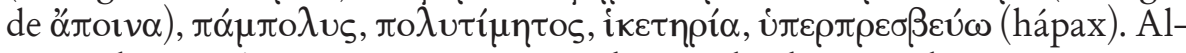
gunos de esos términos y expresiones a las que dan lugar traducen a veces con relativa exactitud otros correspondientes del pasaje iliádico, dejando traslucir

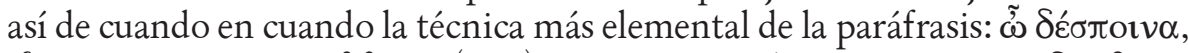

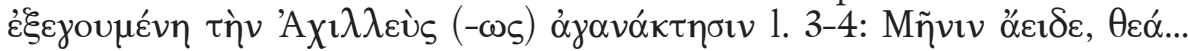

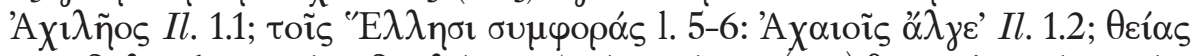

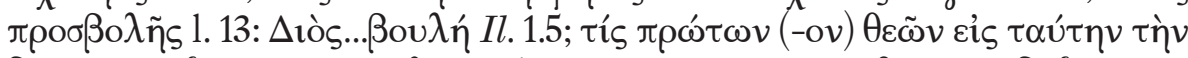

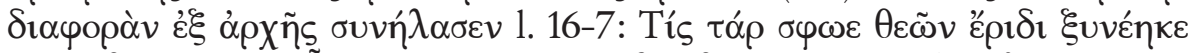

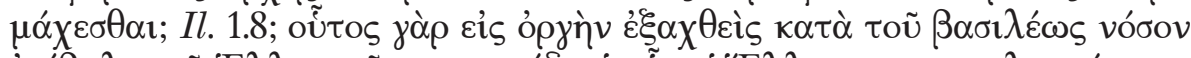

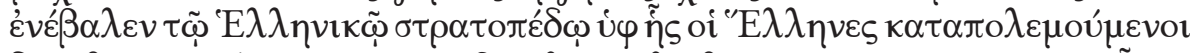

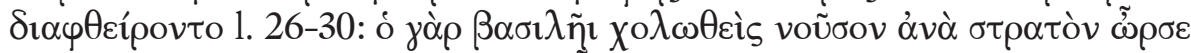

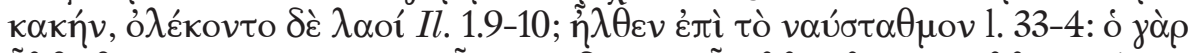

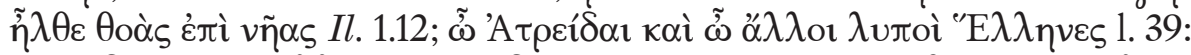

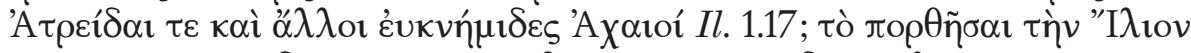

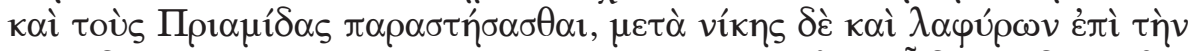

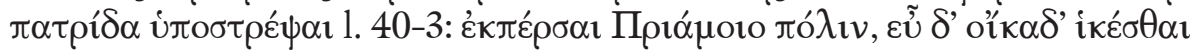

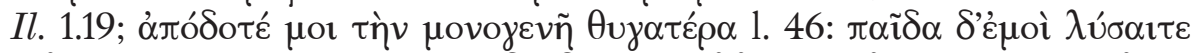

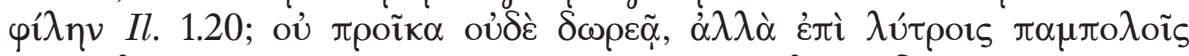

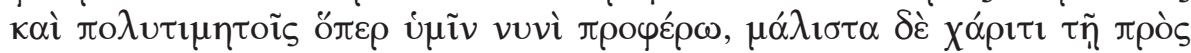

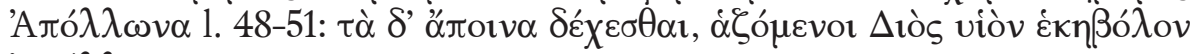
'Aтó $\lambda \lambda \omega v \alpha$ Il. 1.20-1.

El tipo de letra es definido por Parsons ${ }^{54}$ como una semiuncial rápida y propia de un escriba experimentado, no de un alumno cualquiera. Las faltas

${ }^{54} Z P E$ 6, 1970, 141. 
cometidas no son muchas y se explican bien en un escrito al dictado, aunque tampoco extrañan como descuidos de copia, que es la duda que tiene Parsons ${ }^{55}$; y como copia se entiende mejor que, una vez terminado, el texto comience a ser escrito de nuevo en sus cuatro primeras líneas. Sin embargo, el hecho de que el escriba haya interrumpido la última palabra del texto (1.57

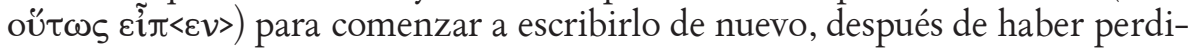
do tiempo en cambiar a un cálamo de trazo más fino tras otra interrupción anterior $(1.56)^{56}$, podría denotar el apresuramiento propio del dictado, más que de la copia. En cualquier caso la paráfrasis del pasaje más socorrido de la Ilíada, que es su comienzo, previamente compuesta por alguien con una formación retórica sin duda muy superior a la del escriba, fue utilizada en esta ocasión como modelo de escritura dentro de los diversos usos, escolares y no escolares, a los que el ejercicio podía prestarse en su función de recrear el imprescindible texto homérico en un tiempo en que este ya no se entendía.

\section{P. Ant. III 143 (LDAB 2128=Mertens-Pack 1206.1)}

En el verso, muy dañado, de una hoja de papiro en cuyo recto se halla $P$. Ant. II $99^{57}$, este testimonio contiene unos pocos restos, escritos contra las fibras, de dos fragmentos de columna, de 7 x $5,5 \mathrm{~cm}$. y 6 x $13,5 \mathrm{~cm}$. respectivamente, en un tipo de escritura pequeño y apretado, cuya tinta se halla borrada en gran parte del primer fragmento y en la parte baja del segundo. Fechado por su editor, J. W. B. Barns, en el s. IV, este advierte de que se trata de una paráfrasis homérica tan libre que los escolios, léxicos y otras paráfrasis de Homero apenas pueden ayudar a la recuperación del texto; la dificultad se ve acrecentada por el frecuente uso de contracciones por parte del escriba, generalmene supliendo desinencias pero también a veces sílabas interiores de términos conocidos que hay que sobrentender ${ }^{58}$.

De los escasos restos de siete líneas que se conservan de la primera columna el editor considera que anteceden al texto cuyos restos conserva la segunda columna, si bien confiesa ignorar cuáles son exactamente sus posiciones relativas $^{59}$. Sus dos únicos términos identificables son derivados de la misma raíz,

${ }^{55}$ ZPE 6,1970,141. Cf. también L. del Corso, "Libri di scuola", 82-4. Las faltas son: $\pi \alpha \rho \imath \sigma \tau \tilde{\alpha} \sigma \alpha$

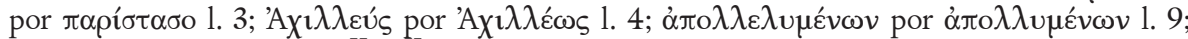

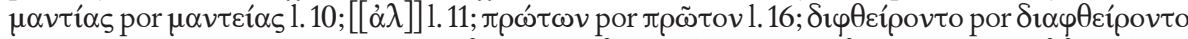

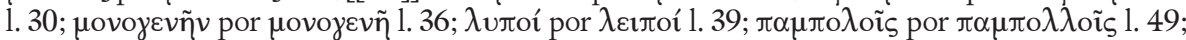

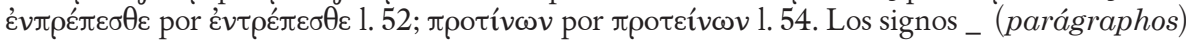
y $\%$ son utilizados por el escriba para indicar pausas mayores.

${ }^{56}$ Cf. P. Parsons, ZPE 6, 1970, 141.

${ }^{57}$ Fechado en el temprano s. IV, contiene dos fragmentos de una petición sobre la alimentación de un menor escrita a lo largo de las fibras con elegante mano literaria y notando puntos altos y diástoles.

${ }^{58}$ The Antinopolis Papyri, III, Ed. with Transl. and Notes by J. W. B. Barns \& H. Zilliacus, London 1967, 75-7.

${ }^{59}$ The Antinopolis Papyri, III, p. 77 


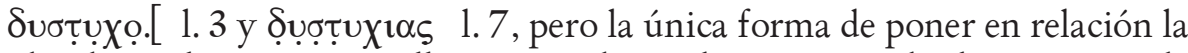
idea de "mala suerte" por ellos expresada con lo que antecede al argumento de los versos 551ss. del canto XXIII de la Ilíada, a partir de los cuales comienza a reconocerse lo que resta de la columna II de la paráfrasis, es si acaso lo dicho por Antíloco a Aquiles en el v. 545, que piensa dar el segundo premio de la carrera de carros a Eumelo porque no fue él sino "el carro y los caballos los que le fallaron".

Si se tiene en cuenta que siete son las líneas con restos de escritura en la col. I y seis las que preceden a la primera línea a partir de la cual parece reflejarse el contenido de $I l$. 23.551-68, el pasaje homérico parafraseado podría comenzar tal vez en el v. 536 y comprender por tanto, dentro del relato de los juegos fúnebres en honor de Patroclo: la propuesta de Aquiles de conceder el segundo premio a Eumelo, hijo de Admeto, que había llegado el último, y el primer premio a Diomedes, moción aplaudida por todos los Aqueos; réplica de Antíloco, hijo de Néstor, instando a Aquiles a que dé a Eumelo un regalo de sus posesiones y rechazando entregarle la yegua que constituye el premio; aceptación por parte de Aquiles, que ofrece dar a Eumelo la coraza que le quitó a Asteropeo; y finalmente el anuncio de la intervención de Menelao, enfadado con Antíloco (el cual le había adelantado por poco en la carrera con malas mañas).

Las secuencias textuales recuperadas por el editor de la paráfrasis en su segunda columna y las que podemos confrontar en el pasaje de Ilíada 23 son:

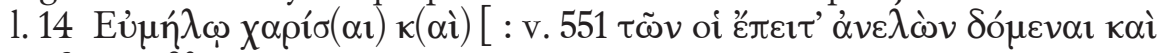
$\mu \varepsilon \tilde{i}$ ov $\alpha$ ó $\theta \lambda$ ov

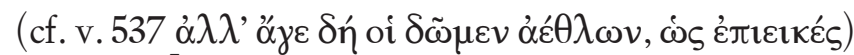

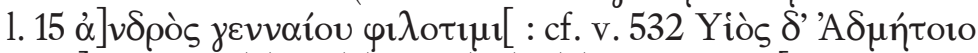

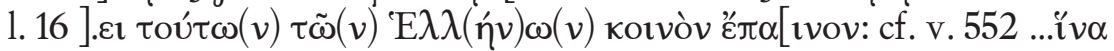

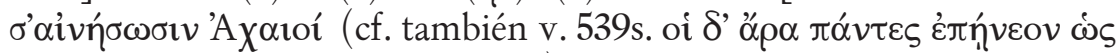

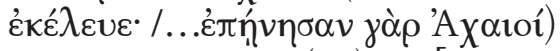

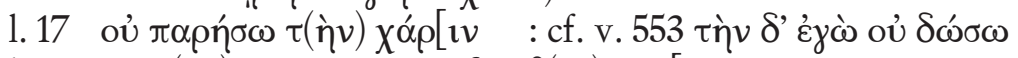

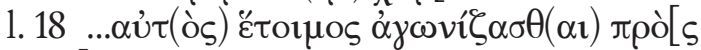

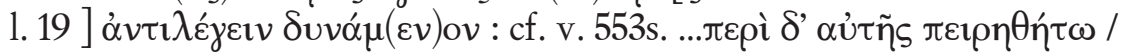

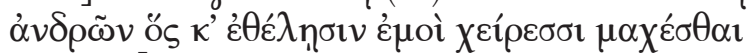

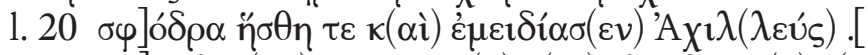

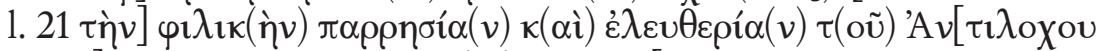

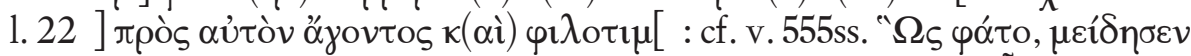

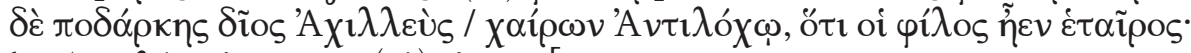

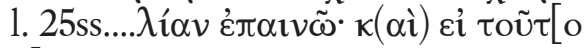

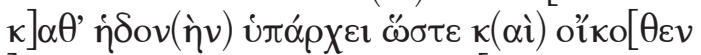

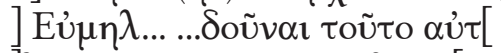

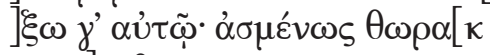

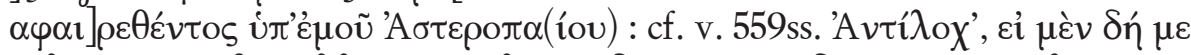

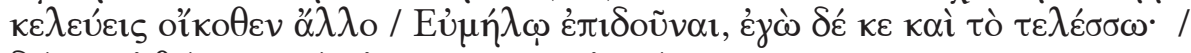

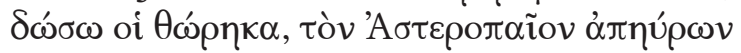




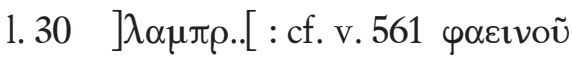

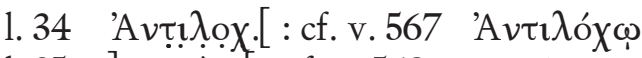

1.35 ]

Como vemos, las secuencias textuales que se pueden recuperar de la paráfrasis remiten a tres intervenciones fundamentales e igualmente sucesivas de la citada sección de Ilíada 23, que son: la de Antíloco describiendo a Aquiles su propuesta de premio a Eumelo (1. 14-9: cf. Il. 23.551-4), la respuesta de Aquiles aceptando su idea (1. 20-30: cf. $I l$. 23555-62) y el comienzo de la intervención de Menelao enfadado con Antíloco (1. 34-5: cf. Il. 23.566-8). Mas no solo hay una correspondencia secuencial entre el texto fuente y la paráfrasis, sino que un cierto número de términos significativos encuentran coincidencia en ambos textos y en el mismo orden; otros términos importantes no se corresponden desde el punto de vista léxico pero sí por su significado.

Con todo, la paráfrasis muestra una cierta tendencia a la expansión y a la perífrasis, como su propia extensión demuestra, siendo sin duda este el aspecto que más la desfigura con respecto al original (cf. por ejemplo 1. 18-9 y v. $554 ; 1.21-2$ y v. $556 ; 1.25-7$ y v. 559 s.; $1.28-9$ y v. 561 ). Otro aspecto que contribuye de manera esencial a ese distanciamiento es, naturalmente, el propio carácter de la paráfrasis, la cual, aunque acompañada en este caso de ciertas

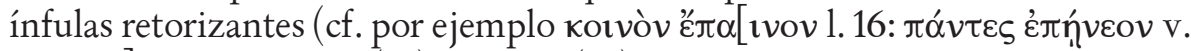

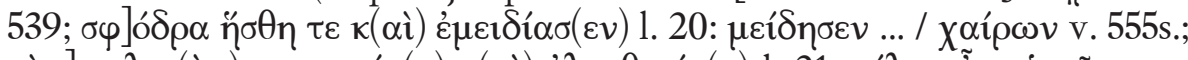

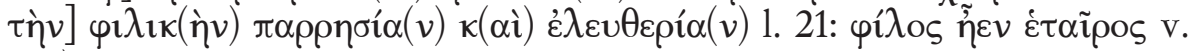
556), al cabo tiene como objeto inmediato expresar el pasaje homérico en cuestión en la lengua prosística de la época, lo cual implica la sustitución sistemática de los términos del epos por los correspondientes de la koiné, la supresión del juego de partículas épicas y de fórmulas homéricas (cf. p.

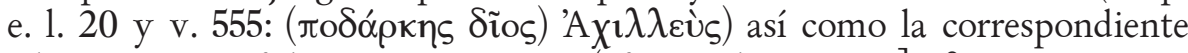

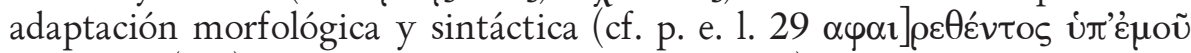

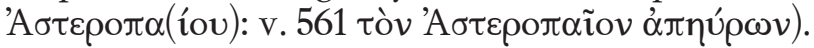

Aunque el editor del texto papiráceo no dice nada al respecto, tanto el tipo de escritura como el hecho de que figure en el verso de un papiro que contiene un texto documental en el recto (P. Ant. II 99), así como el uso de frecuentes contracciones desinenciales o de términos bien conocidos ( $\tau$ oú $\tau \omega(v) \tau \tilde{\omega}(v)$

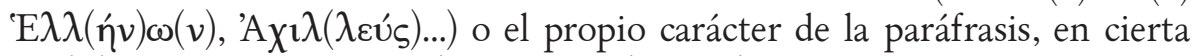
medida retorizante y no solamente traslacional, invitan a pensar en un empleo escolar del texto (como considera el catálogo LDAB). El contenido del pasaje homérico, acerca de la disputa por el segundo premio entre los héroes concursantes en la competitiva carrera de carros, tampoco se aviene mal con dicho empleo, sobre todo si el texto tuviera continuación en forma de rollo (como aventura el catálogo LDAB) y comprendiera la discusión y posterior acuerdo entre Menelao y Antíloco (hasta el v. 611), la cual contiene una gran lección de humanidad, al renunciar al premio el uno a favor del otro. 
III

Casos particulares de paráfrasis:

P. Köln I 46 (LDAB 1.603=Mertens-Pack 1187.1)

Es un pequeño fragmento de hoja de papiro $(9,5 \times 4 \mathrm{~cm}$.) que contiene, por un lado, según su editor ${ }^{60}$ una paráfrasis de $I l$. 9.128 ss. o bien de Il. 19.245ss., por el otro lado un documento, siendo escrita la paráfrasis con mano ejercitada que recuerda el llamado por Schubart "strenger Stil" y permite ser fechada en el s. II d. C. Registra un punto alto (1.1) y diéresis (1. 4),

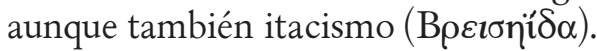

En la medida en que el pequeño tamaño del fragmento permite asegurarlo, el editor cree ver confirmación de que no se trata de un ejercicio escolar en el hecho de que las líneas se hallan separadas unas de otras y la separación entre columnas tiene que haber sido también bastante grande, siendo a su vez $2 \mathrm{~cm}$. lo que resta del margen inferior; hasta el punto de que pudiera darse aquí el raro caso de que la cara con el texto literario sea el verdadero recto del papiro y haya sido escrita antes que la otra cara, de estructura muy irregular y con aspecto de verso.

El editor propone la siguiente lectura del texto:

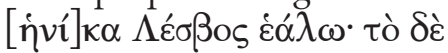

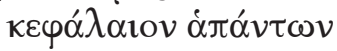

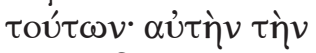

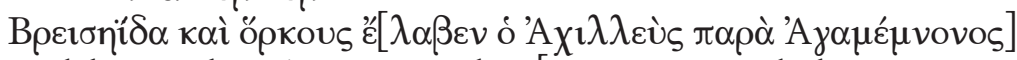

$\mathrm{Y}$ a tenor del texto homérico entiende: "[siete mujeres de las que Agamenón se apropió cuando] fue conquistada Lesbos; y, lo más importante de todo, [Aquiles obtuvo de Agamenón] a Briseida y el juramento..."

El referente homérico sería o bien $I l$. 9.128ss., en que Agamenón, para reconciliarse con Aquiles, se muestra dispuesto a ofrecerle, entre otros regalos, siete mujeres de Lesbos que él se había quedado para sí tras haber sido conquistada por Aquiles, y en octavo lugar a Briseida, así como a jurar que no había compartido el lecho de esta ${ }^{61}$; o bien $I l$. 19.245ss., donde dichas decisiones son puestas en marcha y las promesas se hacen realidad. Si la relación de este segundo pasaje homérico con el texto del papiro resulta, a mi modo de ver, demasiado laxa y los datos comunes aparecen allí harto dispersos para que pueda hablarse de paráfrasis, la conexión en cambio con los versos 129-32 concretamente del canto 9 en lo que respecta tanto a los datos clave y sin adi-

${ }^{60}$ A. Henrichs, "Iliasparaphrase", $Z P E$ 1, 2, 1967, 111-2.

${ }^{61} \mathrm{Il} .9 .128-33$

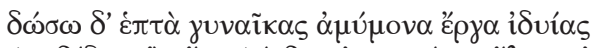

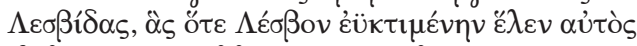

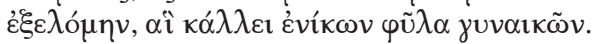

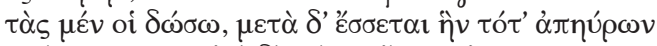

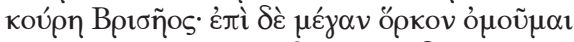

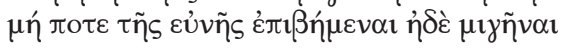




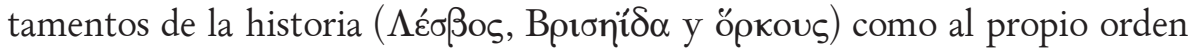
en que se suceden, parece lo suficientemente estrecha para hacer pensar en paráfrasis más que en resumen, a pesar de lo poco que da de sí el texto. A ello se puede añadir un rasgo muy característico de la paráfrasis de tipo retorizante que consiste en dotar al ejercicio de su propia lógica, al margen del relato homérico (cf. supra el caso de Bodleian Greek Inscription 3019): a ello

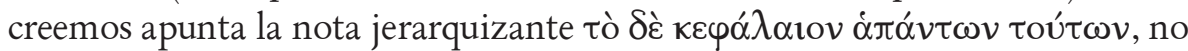
presente en el texto homérico.

P. Oxy. 3002 (LDAB 2124=Mertens-Pack 1857.31)

El argumento principal de la interpelación de Atenea a Aquiles en Ilíada 1.207-14, que es instarle a poner fin a su disputa con Agamenón y resolverla no a golpe de espada sino de palabra, es recogida, con la mayoría de sus diversos detalles, en la composición de P. Oxy. 3002:

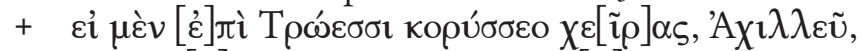

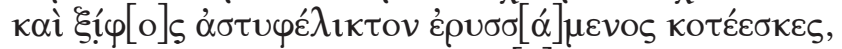

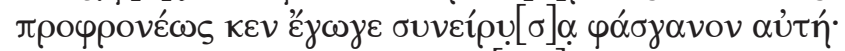

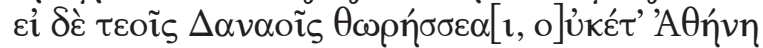

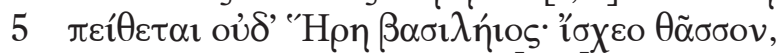

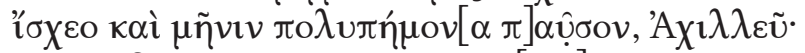

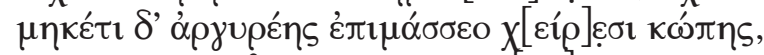

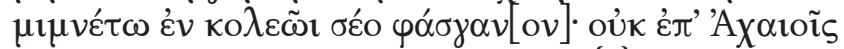

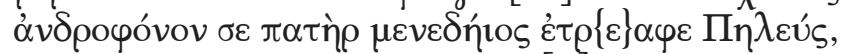

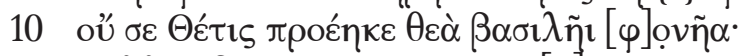

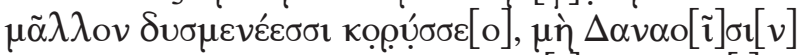

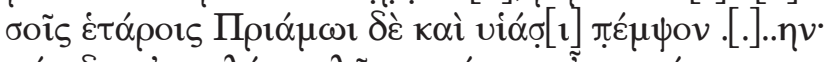

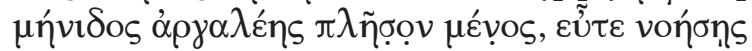

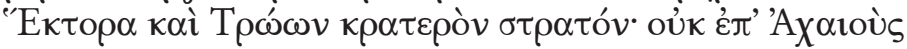

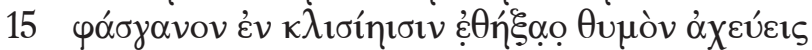

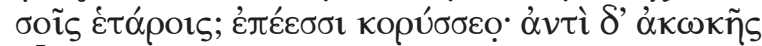

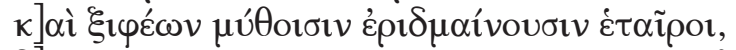

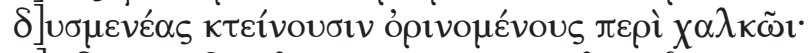

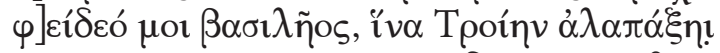

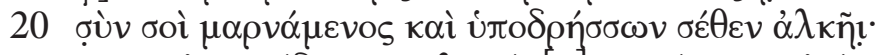

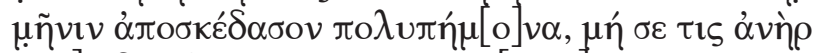

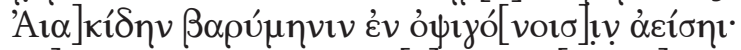

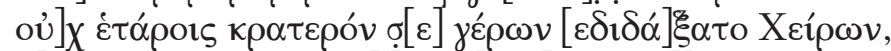

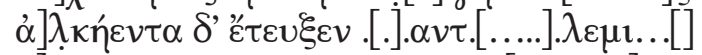

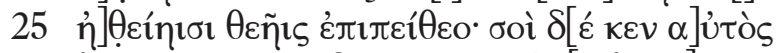

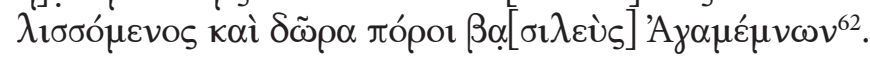

${ }^{62}$ Cf. Il. 1.207-14

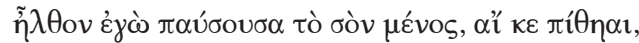


"Si contra los Troyanos armaras tus brazos, Aquiles, y desenvainando tu espada imbatible te enojaras, de buen grado yo misma desenvainaría contigo mi espada, pero si es contra los tuyos, los Dánaos, contra quienes te acorazas, ya no te hace caso Atenea ni tampoco la real Hera. Contente presto, contente y calma, Aquiles, tu muy funesta cólera; no tientes con tu mano la argéntea empuñadura, permanezca en la vaina tu espada. No contra los Aqueos te crió para matador de hombres tu padre Peleo, firme ante el enemigo, no para asesino del rey te dio a luz la divina Tetis; mejor ármate contra los enemigos, no contra los Dánaos tus compañeros sino contra Príamo y sus hijos envía...; llena tu alma de penosa cólera cuando veas a Héctor y el poderoso ejército de los Troyanos. No contra los Aqueos aguzaste en la tienda tu espada. ¿Estás disgustado en lo más hondo contra tus compañeros? Ârmate de palabras; en lugar de a punta de espada los compañeros disputan de palabra, dan muerte a los enemigos que en torno al bronce se lanzan.

Preserva al rey, te advierto, para que arrase Troya luchando contigo y colaborando con tu fuerza.

Disipa tu muy funesta cólera, no sea que algún hombre en las generaciones futuras cante al Eácida de cólera pesada.

No fuerte ante tus compañeros te enseñó a ser el viejo Quirón, sino que te hizo forzudo ....................

Obedece a las diosas leales, $\mathrm{y}$ puede que el propio rey Agamenón te suplique y te ofrezca regalos."

El texto, completo salvo algunas pequeñas lagunas, ocupa la mitad superior de una hoja, de 17 x $27 \mathrm{~cm}$., cuya parte inferior y posterior están en blanco, con un tipo de letra bizantina común entre los s. III y VI que el editor, P. Parsons, sugiere situar en el s. IV y que tanto por su calidad como por la ortografía (diéresis notada consistentemente, marca de elisión de vez en cuando, iota adscrita sin apenas omisiones, no itacismo) califica de a very professional piece $e^{63}$. Solo que, frente a la concisión de la interpelación homérica, la del papiro se recrea en dicho argumento y lo deriva a un enfrentamiento con el

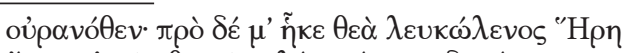

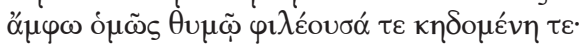

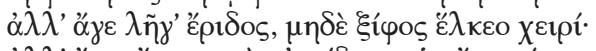

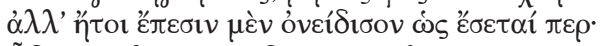

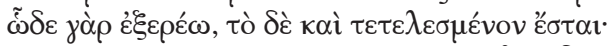

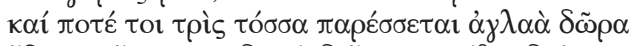

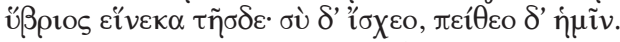
${ }_{63}$ P. Oxy. XLII, 3002, 1974, Ed. P. Parsons, 13-5. 
conjunto de los Aqueos contraponiéndolo a su proceder frente a los Troyanos

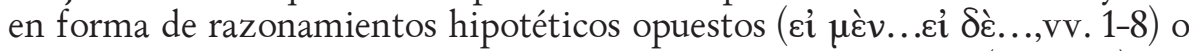
de leve variación, directamente imperativa, de este argumento (vv. 13-5), así como de apelación al destino que su padre Peleo, su madre Tetis y su maestro Quirón concibieron para el héroe (vv. 9-12, 23-4), de exhortación a preservar la vida del rey para que luche con él por la derrota de Troya (vv. 19-20) y del que sin duda constituye el único golpe de ingenio tras la repetitiva exhorta-

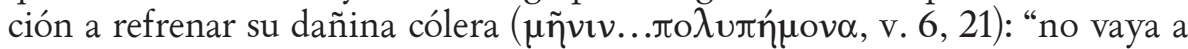
ser que en futuras generaciones alguien cante al Eácida de pesada cólera" (v. 21), en alusión evidentemente a Homero. El núcleo argumental del pasaje homérico, el cual se concentra justamente en sus dos versos centrales ( $\alpha \lambda \lambda$ '

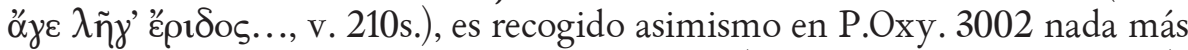

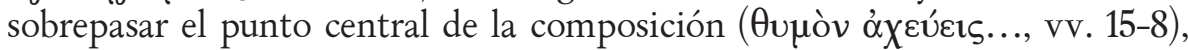
solo que, como es habitual en el retorizante estilo de la composición, sustituyendo la mera exhortación del texto homérico por una secuencia de exhortación más enunciado gnómico que la justifica desdoblándose a su vez en forma antitética (vv. 16-8). Del mismo modo, el contenido de los dos últimos versos (213-4) del discurso de Atenea en Homero sirve también de coronación a la composición papirácea en sus dos últimas líneas (ỉ] v. $25 \mathrm{~s}$.).

La composición podría ser clasificada como ethopoiía ${ }^{64}$ e incluso podría adjudicársele un posible título adecuado a este progýmnasma, del tipo "¿Qué palabras diría Atenea a Aquiles a punto de atravesar a Agamenón con su espada?". Se trataría, de acuerdo con la teoría de los rétores ${ }^{65}$, de una ethopoiía simple, ya que consiste en un discurso sin réplica, y ethiké, puesto que en su caracterización predomina el componente moral sobre el patético. Y muestra rasgos característicos de la etopeya cuales son la acumulación (aunque en exceso repetitiva: vv. 11-5 son mera exhortación en positivo de lo expresado hipotéticamente en el entimema inicial, vv. 1-5) de argumentos exhortativos hasta cierto punto originales (armarse contra los enemigos, no contra los compañeros; apelar a los principios que le infundieron sus padres y a la educación que le dio Quirón; preservar la vida del rey para que le ayude en la conquista de Troya y en particular el ingenioso metargumento de evitar ser objeto de un canto hostil en el futuro), alguno de los cuales (vv. 15-6) se expresa en forma de interrogación retórica, que es un detalle no infrecuente en el género. El problema es que, a diferencia de lo que ocurre con la ethopoiía, la cual suele recrear la reacción de un determinado personaje en una situación conocida del mito y en términos propios (aunque el lenguaje pueda ser básicamente homérico), en la presente composición el elemento propiamente exhortativo, al margen del citado componente argumental, sigue demasiado

${ }^{64}$ Tal como la clasifica P. Parsons, $P$. Oxy. XLII, 3002, p. 13, aunque con reservas.

${ }^{65}$ Cf. Hermog. 21 Rabe. 
de cerca el núcleo discursivo del breve pasaje homérico correspondiente y hasta se distribuye en zonas (centrales y final) que se corresponden con las de su ubicación en el pasaje homérico, a saber:

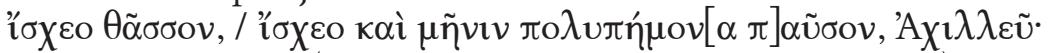

( $\mu \tilde{\eta} \nu \imath v \dot{\alpha} \pi \circ \sigma \kappa \varepsilon ́ \delta \alpha \sigma o v \pi \mathrm{o} \lambda u \pi \tilde{\eta} \mu \mathrm{ov \alpha} \alpha$ v. 21)

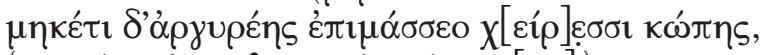

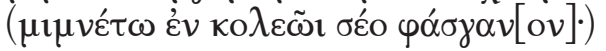

vv. 5-8

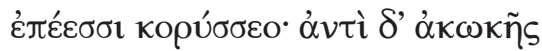

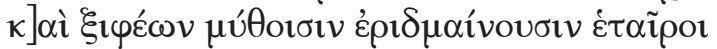

vv. $16-7$

Cf. Il. 1.210-1

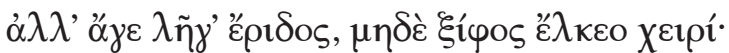

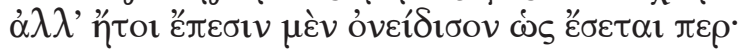

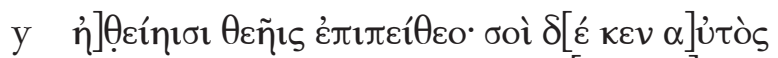

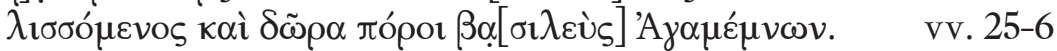

Cf. Il. 1.213-4

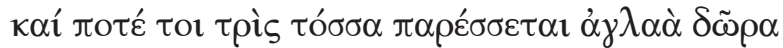

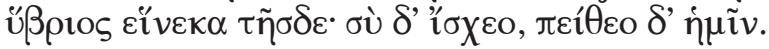

Es más, las divergencias esenciales entre la versión de Ilíada y la de P.Oxy. 3002 en lo que concierne a este común componente exhortativo, parecen obedecer igualmente a un mero afán de expansión por parte de la composición papirácea.

Por otra parte, la presencia de la fraseología de $I l$. 1.207-14 en el papiro no se reduce a la que acabamos de señalar en las secciones más estrechamente conexas, sino que también en otras secciones hallan responsión términos

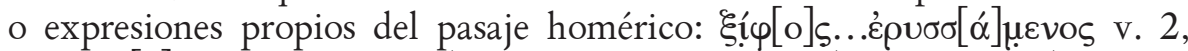

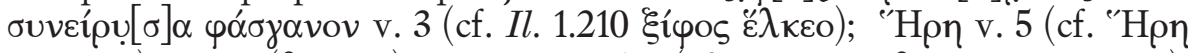

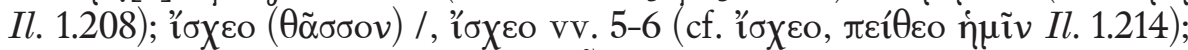

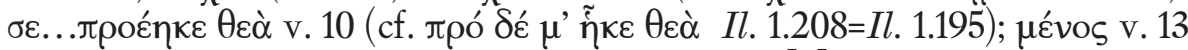

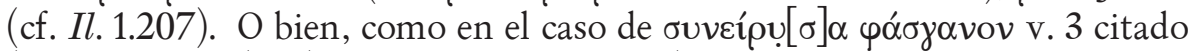

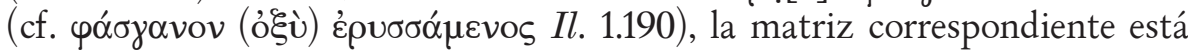

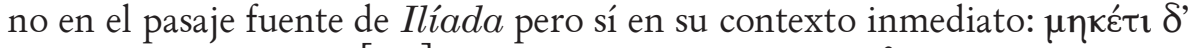

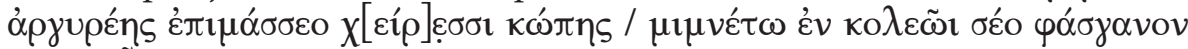

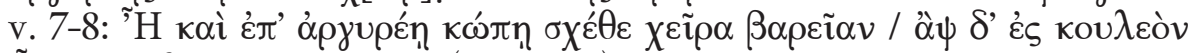

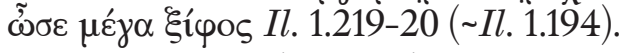

La composición papirácea, pues, puede ser clasificada como ethopoiía en cuanto a su actitud, en la medida en que imita el proceder de un personaje mítico en una situación característica, y también por el tipo de lengua que emplea, cuya base predominantemente homérica se combina con términos épicos de época posterior y algunos en particular pertenecientes al tipo de poesía hexamétrica noniana ${ }^{66}$, al igual que sucede en otras manifestaciones

${ }^{66}$ Cf. P. Parsons, P. Oxy. XLII, 3002, 14-5. 
del género ${ }^{67}$. Ahora bien, desde el momento en que sigue tan de cerca un determinado pasaje homérico al que ligeramente varía y amplía añadiéndole algunos argumentos, en parte fácilmente derivables de la fuente y conteniendo a su vez términos y expresiones contextuales del pasaje homérico, la técnica composicional coincide más bien con la de la paráfrasis. Dada, sin embargo, la ausencia de un rasgo característico y funcional de la paráfrasis que es la "traducción" del lenguaje homérico a la prosa de la koiné, en este caso deberemos hablar no de paráfrasis sino de metáfrasis, que es como se denomina la paráfrasis en verso. Si bien no se conocen otros ejemplos de metáfrasis homéricas en papiro ${ }^{68}$, sí que las tenemos de otros géneros, como, entre otros ejemplos que se podrían citar, la metáfrasis en coliambos de alguna fábula de Babrio transmitida en las Tablillas Assendelft o de algunos de los once primeros versos de la introducción a su corpus de fábulas contenida en el llamado cahier d'écolier P.Bouriant 1 (=P.Sorbonne 826) ${ }^{69}$. También sabemos

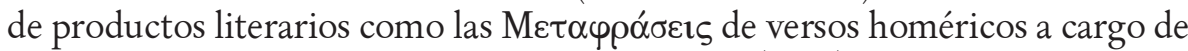

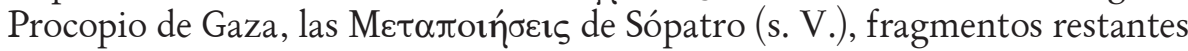
de cuya obra muestran hasta 72 reescrituras diferentes de $I l$. 17.629-42, o

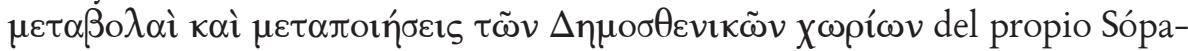
tro $^{70}$. De hecho la paráfrasis, particularmente ligada a la práctica de progymnásmata como el mythos (fabula) o la propia ethopoiía, es considerada por Teón (s. I), el primero de los autores de teoría progimnasmática de los que se conserva obra escrita, como un ejercicio más de preparación a la retórica, del cual hacen frecuente uso tanto poetas como prosistas y que debe ser practicado desde el comienzo mismo de dicha formación ${ }^{71}$; su pariente la exergasía o elaboración, la cual consiste en pulir y redondear un pensamiento mediante la variación de su formulación elocutiva y de los pensamientos secundarios a la idea principal ${ }^{72}$, tal como parece ser el caso en la metáfrasis homérica de $P$. Oxy. 3002, es recomendada cuando se disponga ya de algún dominio.

${ }^{67}$ Cf. J. A. Fernández Delgado \& J. Ureña Bracero, Un testimonio de la educación literaria griega en época romana: IG XIV 2012=Kaibel, EG 618, Universidad de Extremadura 1991, 49-52; J. A. Fernández Delgado, "Hexametrische ethopoiíai auf Papyrus und anderen Materialien", Proceedings of the XX International Congress of the Papyrologists , Ed. A. Bülow-Jacobsen, Copenhagen 1994, 299-305; L. Miguélez Cavero, Poems in Context: Greek Poetry in the Egyptian Thebaid 200-600 AD, Berlin-New York 2008, 121-61.

${ }^{68}$ P. Parsons, P. Oxy. XLII, 3002, 13.

${ }^{69}$ Cf. J. A. Fernández Delgado, "Babrio en la escuela greco-latina", en Homo romanus, sermo graecus. Literatura griega en el mundo romano del s. II al IV (Actas Coloquio Internacional Univ. Barcelona 12-14 marzo 2009), Barcelona (en prensa).

${ }^{70}$ Cf. P. Parsons, ZPE 6, 1970, 140.

${ }^{71} \mathrm{Cf}$. Theo 62, 10-64, $27 \mathrm{Sp}$.

${ }^{72} \mathrm{H}$. Lausberg, Manual de retórica literaria (Versión españ. de J. Pérez Riesco), Madrid 1966, 2, 830 y ss. 
O. Col. inv. 949 (LDAB 117723= Mertens-Pack 1174.001)

Un ejemplo ilustrativo de afinidad entre scholia minora y paráfrasis de tipo gramatical en época avanzada es proporcionado por $O$. Col. inv. 949, datado en el s. $\mathrm{VI}^{73}$, el cual ofrece cuatro breves líneas, según su editora, $\mathrm{R}$. Cribiore ${ }^{74}$ correspondientes a cuatro manos distintas de escritura estilizada y próxima a un tipo de mayúscula inclinada, de posible ejercitación escritu-

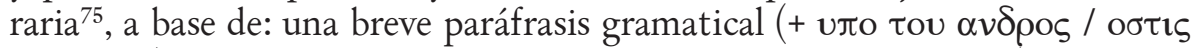

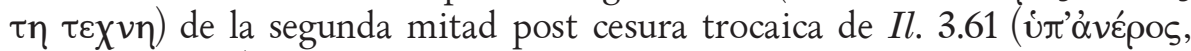

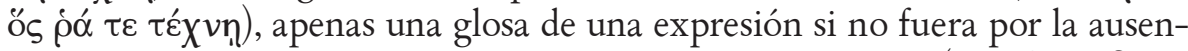

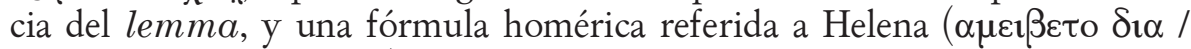
juvolkcov: $I l .3 .171,228)$ e igualmente post cesura trocaica, cada una de las cuales se distribuye sucesivamente en dos de las cuatro líneas del óstrakon. Estas se hallan situadas en el centro de la superficie del óstrakon, de 13, 3 x 7, 2 $\mathrm{cm}$., precedidas de un crismón (como en el caso de $P$. $O x y .3002)^{76}$ y dejando amplios márgenes abajo y a la derecha; de ellas las dos primeras imitan un estilo literario y las otras dos una mano documental, con ligaduras y al final una rúbrica, rasgo este que, con la cruz inicial del texto, indica que el ejercicio, por difícil de imaginar que su función sea, no iba más allá de lo conservado ${ }^{77}$.

Sospecho que en la inquietante elección de los textos ha tenido que ver, primero, como supone Cribiore, el intento de familiarización con mitades de verso (y no solo hexámetros) y con cesuras que se encuentra a veces en papiros escolares (cf. P. Ryl. 3545 (n 291 Cribiore): primera mitad de los versos 122-50 de Od. 9; P. Bouriant 1 (=P. Sorbonne 826): veinticuatro gnomae monostichoi más los once primeros versos del primer prólogo de las fábulas de Babrio con cada verso distribuido en dos líneas coincidiendo con la cesura); segundo, el hecho de que ambos segmentos de verso proceden del mismo contexto del combate cuerpo a cuerpo entre Paris y Menelao del canto 3 de Ilíada en que, primero, Paris responde a la reprimenda de su hermano Héctor comparando su inflexible carácter con el hacha en manos del carpintero (Il. 3.61) y más tarde Helena se dispone a contestar a Príamo $(I l .3 .171,228)$ quién es cada uno de los caudillos griegos que pasan al pie de la muralla.

Casos de paráfrasis destinadas a un ámbito más amplio que el meramente escolar, a diferencia de las dos últimas, parecen ser:

${ }^{73}$ Cf. P. Oxy. 43.3150, de esa misma época y procedente como este de un contexto monástico.

${ }^{74}$ R. Cribiore, "Homer on a Puzzling Ostrakon", BASP 45, 2008, 41-4.

${ }^{75}$ Un precedente de ello puede ser $P$. Oxy. 68.4669, en que un mismo escriba practicó diferentes estilos.

${ }^{76} \mathrm{El}$ óstrakon griego fue un hallazgo aislado entre un elevado número de óstraka coptos en el templo y monasterio de Deir el Bahari, en el Alto Egipto, sobre el cual cf. A. Lajtar, Deir el-Bahari in the Hellenistic and Roman Periods: A Study of an Egyptian Temple based on Greek Sources, Warsaw 2006, espec. 94-104.

${ }_{77}$ R. Cribiore, $B A S P 45,2008,43$, piensa en un tipo de ejercicio de respuesta a preguntas oralmente formuladas. 
P. Köln IV 180 (inv. 7891) (LDAB 2245=Mertens-Pack 1199.3)

Fragmento de papiro, de 11, 6 × $6 \mathrm{~cm}$., perteneciente a un códice, escrito por ambas caras y mutilado por los cuatro lados, conservando en el verso la derecha de la columna y en el recto la izquierda de esta, en parte mutilada. El tipo de escritura literaria, el promedio de letras por línea calculado (c. 38) y el ancho de columna $\left(15-16 \mathrm{~cm}\right.$.) hacen pensar al editor ${ }^{78}$ en los s. VI-VII como fecha del códice.

Este contendría, según el editor, una paráfrasis de la Ilíada, de la cual el recto del papiro conserva restos de la paráfrasis de $I l$. 16.394-418 y el verso restos de los versos 459-71 del mismo canto. Dicha paráfrasis pertenecería al tipo llamado gramatical, distinto de la paráfrasis retórica, dado que "..hält sich eng an den Homertext, wobei kleinere Details übergangen werden...und bemüht sich offensichtlich um einfache Wortwahl"79.

Ahora bien, si algo no vemos claro en los restos del papiro es su "estrecha adhesión al texto homérico". Los restos del recto reconocibles a partir de este se distribuyen en nueve líneas que el editor considera que cubren los versos 394-418 de Il. 16 y que en mi opinión alcanzan hasta el v. 420 (es decir, un

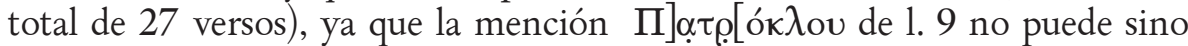
referirse a la nueva mención de Patroclo que da inicio al relato de su lucha con Sarpedón (Il.16.419ss.), a continuación del relato de la Patroclía ante Troya. De las ocho líneas anteriores, las cuatro últimas, las más completas, recogen claramente la escueta lista de guerreros troyanos abatidos por Patroclo, eso sí en el mismo orden, que en $\mathrm{Il}$. 16 se extiende a lo largo de los versos 399-419 al incluir, de los tres primeros, la descripción detallada del tipo de muerte recibida. De las cuatro primeras líneas se puede confrontar con el texto homérico, por supuesto en el tipo de lengua característico de la koiné, la mención de Patroclo, la de los troyanos y el impedimento de estos por parte de aquel (¿de acceder a la ciudad?) desviándolos (¿hacia las naves?), según relatan los versos 394-6 en el mismo orden pero incluyendo otros detalles que alcanzan hasta el v. 398.

Ese mismo tipo de paráfrasis tan concisa que omite cualquier detalle que no sea esencial para dar cuenta de las líneas generales del relato, es el que parece entreverse también en los restos del verso del fragmento ${ }^{80}$, los cuales parecen abarcar en sus ocho líneas los catorce versos comprendidos en $I l$. 16.458-71 (no 459-71, puesto que la clara lectura Zeús de la primera línea, sin duda trata de verter de manera directa, de acuerdo con las normas del género, la perífrasis $\pi \alpha \tau \grave{\rho} \rho \dot{\alpha} \nu \delta \rho \tilde{\omega} \nu \tau \varepsilon \theta \varepsilon \tilde{\omega} \nu \tau \varepsilon$ del v. 458). Mejor documentados que en el texto del recto podemos vislumbrar aquí los datos clave, despojados de toda información accesoria pero en el mismo orden, del comienzo del relato tras la decisión de Zeus al respecto, del combate entre Sarpedón y Patroclo.

\footnotetext{
${ }^{78}$ M. Erler, “Iliasparaphrase”, P. Köln IV 180, 1982, 129-33.

${ }^{79}$ Ibid., 128-9.

${ }^{80}$ Cf. J. Spooner, Nine Homeric Papyri, 25 y n. 125.
} 
Veamos:

Recto

fr. $b^{81}$

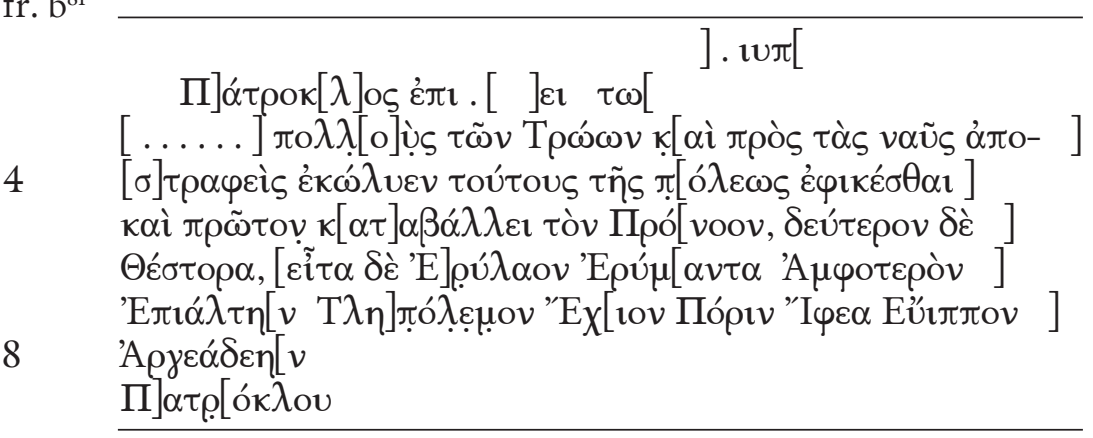

Verso

fr. $b^{82}$

${ }^{81}$ Cf. Il. 16.394-420

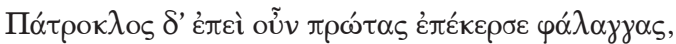

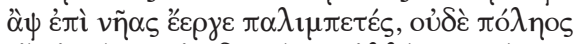

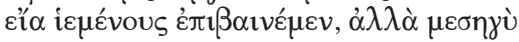

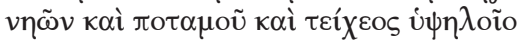

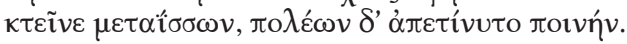

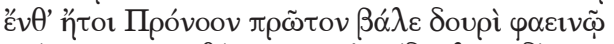

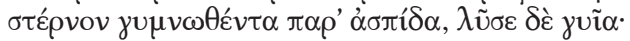

400

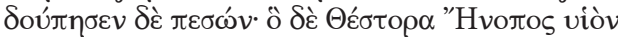

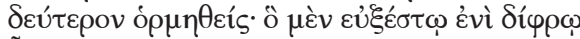

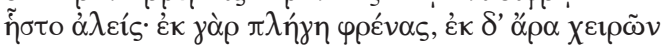

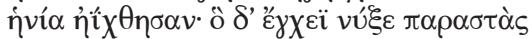

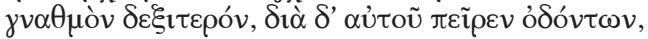

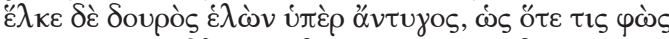

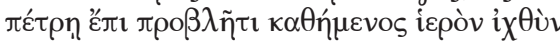

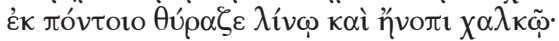

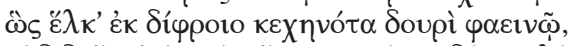

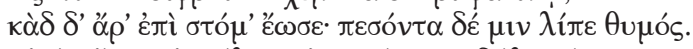

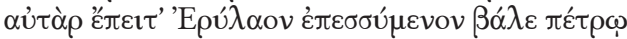

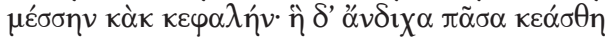

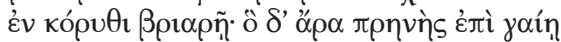

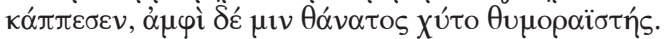

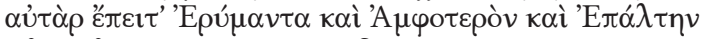

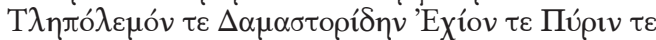

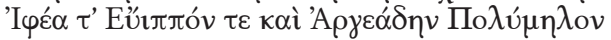

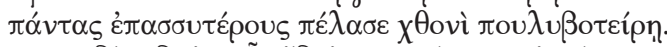

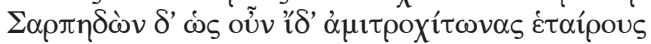

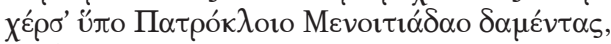

${ }_{82}$ Cf. Il. 16.458-71

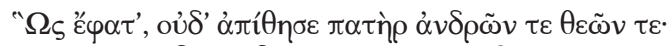

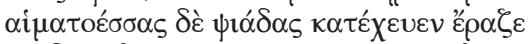

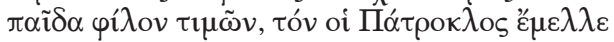

460

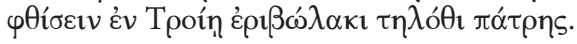




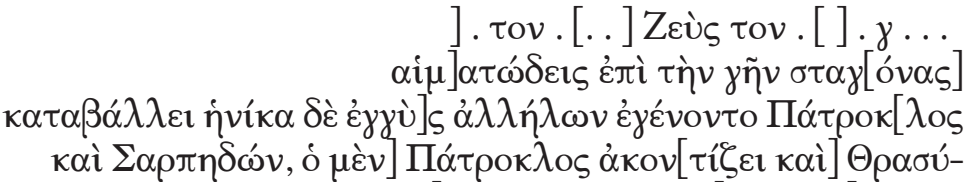

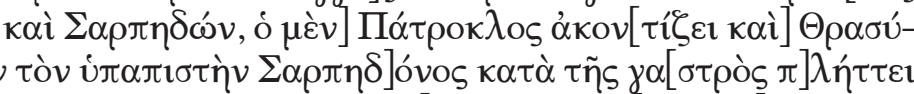

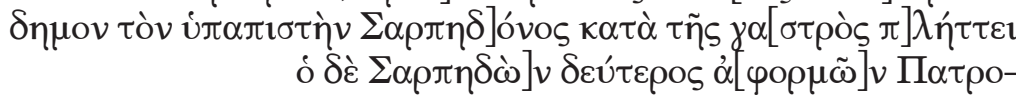
$\tau \alpha \mathbf{r} \kappa \alpha \bar{\alpha}$ $\tau \grave{\alpha} \delta \varepsilon \grave{\eta} \dot{\eta} v i ́ \alpha \sigma v v \varepsilon]_{X} u ́ \theta \eta$

Esta muestra papirácea tiene, pues, el particular interés de que, en un formato de libro de características netamente literarias, proporciona un ejemplo del tipo de paráfrasis retórica, en este caso de una modalidad muy sucinta, que, paralelamente a las conocidas paráfrasis gramaticales de época bizantina, tenían su demanda y su público más allá del estricto marco de las aulas.

\section{P. Vindob. G 26221 (LDAB 2235=Mertens-Pack 1169.1)}

Fragmento de 14, $5 \mathrm{~cm}$. de ancho x $10 \mathrm{~cm}$. de alto proveniente de la parte inferior de una hoja de un códice de papiro escrita en "elegante mayúscula alejandrina" fechada en el s. VI, con indicación ocasional de elisión mediante apóstrofo y de diéresis, rasgos que, unidos a la anchura de los márgenes inferiores supérstites ( 6 y $5 \mathrm{~cm}$.), sugieren un "producto de alta calidad de la antigua industria libresca" $"$.

El recto del papiro conserva, en una primera columna, la segunda mitad del v. 601 y todo el v. 602 del canto 6 de Ilíada, y en una columna enfrente las primeras letras de las dos últimas líneas de lo que debe de haber sido la versión en lengua de la época de las líneas opuestas a juzgar por lo conservado en el verso del papiro y porque en la 1. 5, en el intercolumnio y en letra más pequeña de la misma mano, se conserva la traducción ( $\varepsilon v \delta \varepsilon \eta \varsigma \eta v)$ del término homérico que precede en la línea: $\varepsilon \delta \varepsilon v \varepsilon \tau o$. El verso del papiro, escrito contra las fibras, conserva, en la primera columna, los versos 609-10 del mismo can-

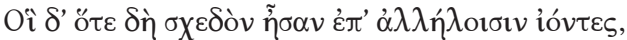

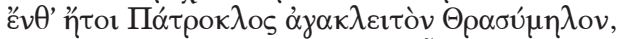

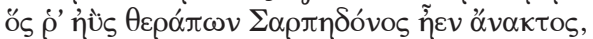

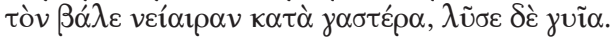

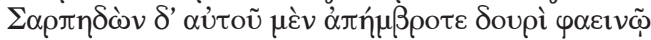

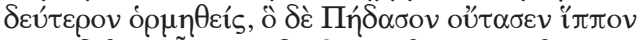

हैชX

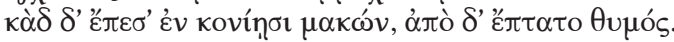

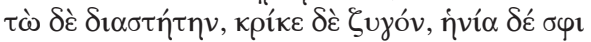

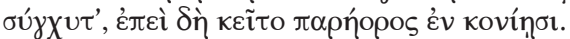

${ }^{83}$ J. Lundon, "P. Vindob. G 26221: Scholia Minora or Paraphrase?", B. Palme (Hrsgb.), Akten des 23. Internationalen Papyrologen-Kongresses (Wien, 22.-28. Juli 2001), Wien 2007, 407-14 (407-08). 
to - unos y otros pertenecientes al párrafo final de este que describe cómo los dioses celebraron un banquete durante todo el día (v. 601ss.) y al llegar la noche cada uno se fue a su casa y Zeus a su lecho (v. 609s.) con Hera- menos el nombre de Zeus (Zeìs $\delta \grave{\text { ) }}$ con que comienza el pasaje; en la segunda columna, a partir de la tercera línea, el significado o traducción de cada uno de los términos opuestos de la columna anterior, sin dejar ninguno de ellos sin versionar, por obvios o incluso iguales que a veces sean. Para ello los términos de cada verso, y sus correspondientes traducciones, son dispuestos cada uno -o bien cada sintagma preposicional, de partículas o, en un caso (v. 8), de epíteto y sustantivo- en su respectiva línea por separado (1-7 en el recto y 1-9 en el verso). Los términos con que comienzan los versos 602 y 610 y la traducción de este último, los únicos comienzos de verso conservados, sobresalen por la izquierda de la alineación de los demás en forma de ékthesis. Veamos:

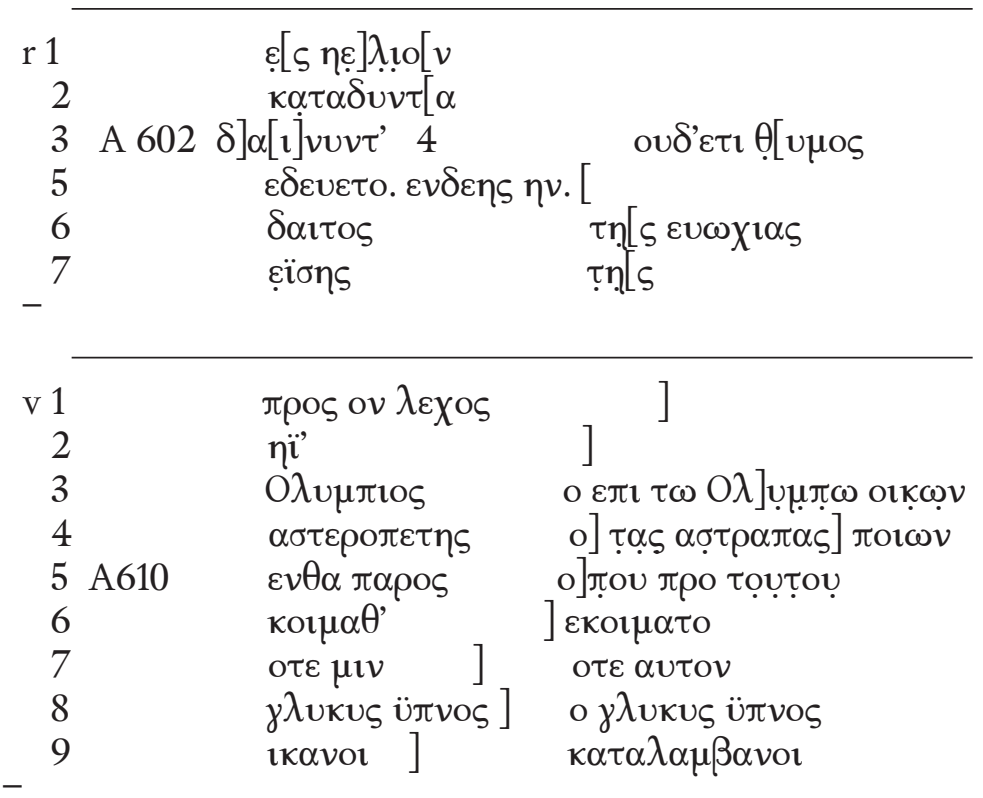

Aunque sendos editores del texto se habían referido a él como paráfrasis ${ }^{84}$, en particular G. Bastianini, quien ha introducido la designación en el título de su trabajo aparte de identificar el pasaje homérico correspondiente, su tesis no ha gozado de general aceptación y L. M. Rafaelli lo incluye en su por otra parte útil Repertorio de scholia minora o glosarios más o menos selectivos de términos y expresiones del texto homérico por orden de aparición ${ }^{85}$. Sin

${ }^{84}$ H. Harrauer, "Ein Homerkodexfragment: P. Vindob. G 26.221”, CodMan 1, 1975, 74-7; G. Bastianini, "P. Vindob. G 26221 riconsiderato (Omero, Il. 1, 601-602; 609-610 con parafrasi)", Prometheus 6, 1980, 83-8.

85 "Repertorio dei papiri contenenti scholia minora in Homerum", en Ricerche di filologia classica (s. n. 1), 139-77 (165 n. 43, 174 n. 64). 
embargo, aun reconociendo que el texto papiráceo comparte dos rasgos característicos de los scholia minora cuales son su disposición en dos columnas enfrentadas, la una conteniendo el texto homérico troceado en palabras o

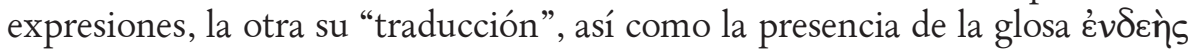
$\hat{\eta} v$ en el intercolumnio de la 1.5 del texto, la cual podría responder a una ulterior explicación introducida entre el lema y su traducción como ocurre con frecuencia en los scholia, J. Lundon ha aducido como paralelo el caso de un papiro de La Sorbona inédito ( $P$. Sorb. inv. 2088) y datable en el s. V d. C., que traduce enteramente los versos 45-57 de $I l$. II, demostrando así no ser scholia, como se creía, sino igualmente una paráfrasis. Como confirmación de su propuesta el estudioso aduce el hecho de que sea destacado en ékthesis el comienzo de cada veso, la presencia de elisión entre líneas, la cual en los glosarios suele por el contrario suplir la vocal elidida, y por supuesto el hecho de que estos textos no dejen ni un solo término sin versionar, aun cuando a veces el término no varía. A este respecto yo destacaría, a propósito de $P$.

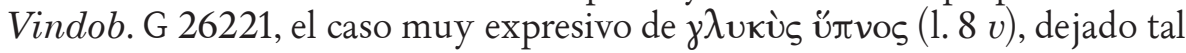
cual por el glosador, incluido su epíteto.

Como ulterior apoyo a su estudio del papiro, Lundon aduce otro testimonio, $\boldsymbol{P}$. Cair. JE 45613, de 3, 3 x $12 \mathrm{~cm}$., proveniente de Oxirrinco, publicado por C. Gallazzi y datado en s. V-VI ${ }^{86}$, el cual contiene restos de los versos 43-5 y 48-50 del canto 1 de Ilíada (sobre la terrible reacción de Apolo a la petición de venganza por parte de Crises) y, como los otros dos papiros, trocea los versos en palabras y breves sintagmas y los dispone en columna, oponiéndoles en otra sus respectivas versiones en prosa coetánea, incluida la de aquellos términos que no varían:
r 1
A 43
cos $\varphi \alpha \tau$ :
2
3
$\varepsilon \cup X 0 \mu \varepsilon v o s:$

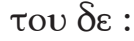
$4 \quad \varepsilon \kappa \lambda \cup \varepsilon$ :
ov] $] \omega \varsigma \varepsilon \varepsilon[\pi \varepsilon$
]uxou[ [
$\tau]$ oựou $[\delta \varepsilon$
..] ฤ.коve
5
Фorßos A $\mathrm{\pi o} \lambda \lambda \omega v$ :
o] $\kappa \alpha[\theta \alpha] \rho[o s \kappa \alpha 1$
6
7
44
$\beta \eta \delta \varepsilon:$
$\alpha \mu 1 \alpha v \tau o]_{s} \mathrm{~A} \pi \mathrm{o}[\lambda] \lambda \omega[v$
8
$\kappa \alpha \tau$ Ov
$\varepsilon] \pi \circ \rho \varepsilon v \theta \dot{\eta} \dot{\delta} \delta \varepsilon$
9

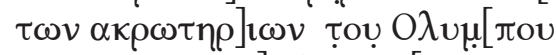

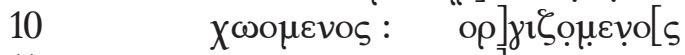
$11 \mathrm{k \eta \rho}$ :

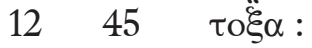

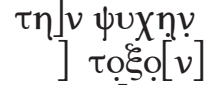
13

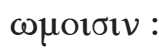
14
EX⿳宀 :

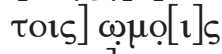

$$
\begin{aligned}
& \text { ]v }
\end{aligned}
$$

86 "P. Cair J.E.45612: scholia minora, o parafrasi, a Homerus, Ilias A 43-5 e 48-50", ZPE 64, 1986, 1-9. 


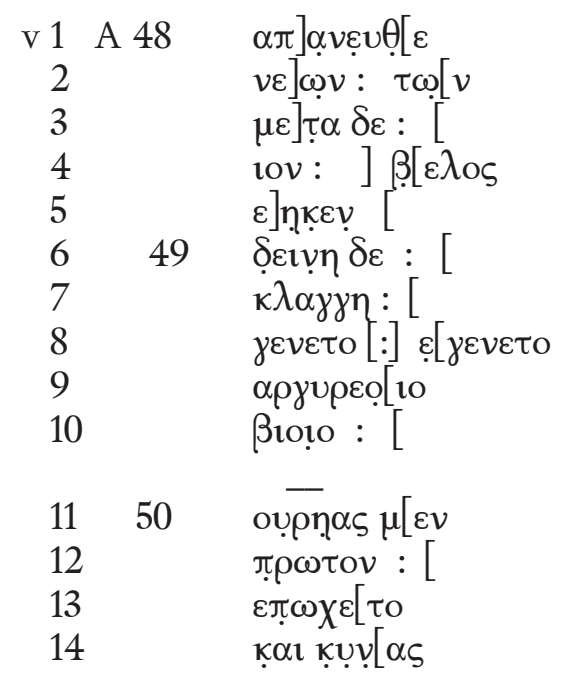

También de la ékthesis, presente a comienzo de verso en $P$. Vindob. G 26221, ve Lundon un equivalente en la parágraphos que separa la última palabra de algún verso de la primera de otro, tanto en $P$. Sorb. inv. 2088 como en $P$. Cair. JE 45613 (1.10 v entre v. 49 y 50), y que como el rasgo anterior es representativo de la idea de continuidad del texto, a diferencia de lo que ocurre en los scholia. Un detalle, sin embargo, no menos indicativo a este respecto no comparte $P$. Cair. JE 45613 con los otros dos testimonios y es la marca de elisión, que este por el contrario sustituye por la vocal suplida (1. 3 $r, 8 v$ ), como es la norma en los scholia minora. Con lo cual surge la duda de si es entre estos donde ha de ser clasificado este útimo testimonio papiráceo ${ }^{87}$ o si por el contrario no se tratará de un efecto más de lo que F. Montanari ${ }^{88}$ llama ósmosis, o interinfluencia observable entre los diversos procedimientos exegéticos del texto homérico. Si esto, como parece, es realmente así, los tres testimonios papiráceos mencionados servirán de ilustración de un formato de paráfrasis del tipo gramatical, presente al menos en época avanzada, que no es ni la paráfrasis interlineal ni la paráfrasis exenta del texto homérico, sino otra que adopta el layout de los scholia minora para, al menos en el caso de $P$. Vindob. G 26221 dadas sus características bibliológicas, permitir leer a Homero a un público mucho más amplio que el escolar y también cada vez más necesitado de ayudas prácticas para conseguirlo ${ }^{89}$.

${ }^{87}$ C. Gallazzi, "P. Cair J.E.45612", 1-9, adopta una postura indecisa entre las dos opciones.

${ }^{88}$ Studi di Filologia Omerica, 2, 72, 81-2.

${ }^{89}$ Cf. ibid. $59-68$. 


\section{IV}

Recapitulando, de los testimonios que hemos podido reunir de paráfrasis homéricas en papiro y otros soportes escriturarios, lo primero que cabe destacar es que el dossier no solo es relativamente abundante sino que abarca un amplio lapso de tiempo que va al menos de la primera mitad del s. I d. C. al s. VI-VII, distribuyéndose los testimonios a lo largo de casi cada uno de los sucesivos siglos. También es de destacar cómo, en lo que el conjunto de testimonios tiene de reflejo de la enorme vigencia de Homero como modelo literario a lo largo de los siglos, la incidencia de aquellos revierte una vez más en las secciones de su obra que sabíamos ya privilegiadas por los hallazgos papiráceos de texto así como de sus diversos pocedimientos exegéticos, a saber, los cantos 1 a 6 de Ilíada preferentemente, el primer canto en particular, y en este caso no solo escasa sino nula representación de Odisea ${ }^{90}$. Otro aspecto importante es que, aunque en algún caso (PSI XII 1276) persiste la duda sobre su pertenencia al medio escolar, otros dos casos (Bodl. Gr. Inscr. 3017 y 3019) se presentan en el tipo de soporte escolar más genuino, que es el llamado school-book de tablillas de madera, y a su vez constituyen sendas manifestaciones verdaderamente notables de los dos tipos más polares que se pueden distinguir en el amplio espectro de este ejercicio: la paráfrasis meramente traslaticia y verbum de verbo, a partir de un glosario que en este caso también la acompaña (Bodl Gr. Inscr. 3017), y la paráfrasis retorizante y exenta de su matriz, que a base de expansiones, explicaciones, duplicaciones y perífrasis consigue triplicar la extensión del texto base y devenir un texto autónomo (Bodl. Gr. Inscr. 3019). Y, lo que es más importante, aparte de dos testimonios del tipo de paráfrasis-traducción (el citado más PSI XII 176) y los métodos de elaboración de que se sirven, los otros testimonios ilustran distintas posibilidades de expansión (el citado más P. Antin. 3143 ) o de contracción (PSI II 135) del ejercicio retórico-parafrástico. Con lo cual, frente al esquema que tradicionalmente contrapone sin más estos dos tipos de paráfrasis, los testimonios aquí reunidos permiten vislumbrar la amplia variedad de posibilidades que se abren ante la paráfrasis retórica, tal como la teoría de los

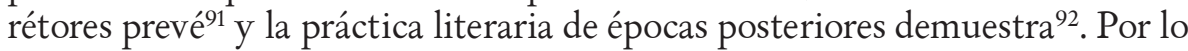
demás, uno y otro tipo de paráfrasis se ven alternar a lo largo de los siglos que van al menos del I-II al VI-VII, tanto en el ámbito escolar como más allá de este, en distintas modalidades de ejecución y en distintos formatos en uno y

${ }^{90}$ Cf. J. M. Díaz Lavado, "Homero y la escuela”, en J. A. Fernández Delgado, F. Pordomingo \& A. Stramaglia (eds.), Escuela y literatura en Grecia antigua (Actas Simposio Internacional Universidad de Salamanca 17-19 noviembre 2004), Università di Cassino 2007, 207-22.

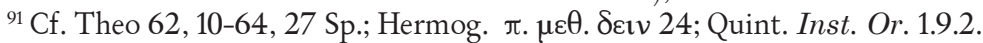

${ }^{92}$ Se sabe de versiones homéricas a cargo de autores de nombre conocido (como Timógenes),

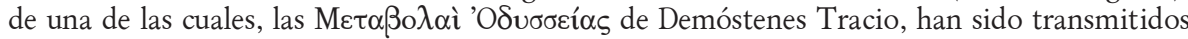
fragmentos por Eustacio que muestran algunas tendencias coincidentes con la paráfrasis de Bodl. Gr. Inscr. 3019, cf. P. Parsons, ZPE 6, 1970, 140. 
otro caso, en su afán por hacer llegar el texto del poeta por excelencia a sus cada vez menos eruditos lectores. 
